\title{
The theory of human development: A cross-cultural analysis
}

\author{
CHRISTIAN WELZEL ${ }^{1}$, RONALD INGLEHART ${ }^{2} \&$ \\ HANS-DIETER KLINGEMANN ${ }^{3}$ \\ ${ }^{1}$ International University Bremen (IUB), Germany; ${ }^{2}$ University of Michigan at Ann Arbor, \\ USA; ${ }^{3}$ Social Science Research Center Berlin (WZB), Germany
}

\begin{abstract}
This article demonstrates that socioeconomic development, emancipative cultural change and democratization constitute a coherent syndrome of social progress - a syndrome whose common focus has not been properly specified by classical modernization theory. We specify this syndrome as 'human development', arguing that its three components have a common focus on broadening human choice. Socioeconomic development gives people the objective means of choice by increasing individual resources; rising emancipative values strengthen people's subjective orientation towards choice; and democratization provides legal guarantees of choice by institutionalizing freedom rights. Analysis of data from the World Values Surveys demonstrates that the linkage between individual resources, emancipative values and freedom rights is universal in its presence across nations, regions and cultural zones; that this human development syndrome is shaped by a causal effect of individual resources and emancipative values on freedom rights; and that this effect operates through its impact on elite integrity, as the factor which makes freedom rights effective.
\end{abstract}

\section{Introduction}

Researchers concerned with development and change in human societies followed three major trajectories of societal change. The most fundamental one - socioeconomic development - has been described as set of closely linked changes including technological innovation, productivity growth, improving health and life expectancy, increasing incomes, rising levels of education, growing access to information and increasing social complexity (among many others, see Lewis 1955; Rostow 1961; Bell 1973; Chirot 1986; Perkin 1996; Rowen 1996; Barro 1997; Estes 1998; Rodrik 1999; Hughes 1999; Sen 2001).

The second process - value change - comes along with socioeconomic development when expanding markets and social mobilization diversify and intensify human activities, such as commercial transactions and civic exchange. These processes strengthen horizontal bargaining relations and weaken verti- 
cal authority relations that restrict human autonomy (Weber 1958; Banfield 1958; Eckstein 1988; Coleman 1988). Fading constraints on human autonomy tend to reshape people's value orientations in ways that have been described in various terms, such as the emergence of 'civic cultural' values (Almond \& Verba 1963), 'individual modernity’ (Inkeles \& Smith 1974; Inkeles 1983), 'postmaterialistic values' (Inglehart 1977, 1990), 'liberal values' (Brint 1984; Flanagan 1987; Nevitte 1996), 'anthropocentric values' (Bürklin et al. 1996) and 'self-expression values' (Inglehart 1997; Inglehart \& Baker 2000). Whatever the terminology, most theories of value change coincide in the notion that traditional conformity values, which subordinate human autonomy to community discipline, tend to give way to more emancipative values that emphasize human choice. Accordingly, we characterize this process as an emancipative value change.

A third major process involves a society's political institutions. The most notable development in this field has been a massive trend towards more democracy. This happened in two ways during the past three decades. Most obviously, many authoritarian regimes changed into formal democracies by adopting democratic constitutions in the 'Third Wave of Democratization' (Huntington 1991; Sørensen 1993; Kurzman 1998; Nagle \& Mahr 1999; Dorenspleet 2000). At the same time, a more subtle change has taken place in established democracies. Since the late 1970s, most of them have implemented or extended direct democratic institutions (Cronin 1999; Scarrow 2001) and they have experienced rising levels of direct civic participation (Barnes et al. 1979; Budge 1996; Dalton 2001; Norris 2002). Some scholars see these changes as an acceleration of a more enduring historical trend towards democracy (Gurr et al. 1990; Modelski \& Perry 1991; Diamond 1993; Jaggers \& Gurr 1995).

As often as the processes of socioeconomic development, emancipative value change and democratization have been described, they have been called into question (see Randall \& Theobald 1998: Chapters 1-2). It has been debated, for instance, whether these processes manifest irreversible linear trends or follow cyclical patterns with major setbacks; whether they are uniformly global or culture-specific in a way that prescribes an inherently Western model; and even whether they are desirable or not.

One point, however, can be hardly denied: if socioeconomic development, emancipative value change and democratization occur, they tend to go together. Poor societies, whose citizens suffer from scarce resources - most obviously in Sub-Saharan Africa - tend to be dominated by conformity values that reflect constraints on human autonomy. These societies are usually governed by authoritarian regimes. Even if they have a democratic constitution, 
such formal democracies seldom operate effectively because highly corrupt elites deprive people of their rights (Heller 2000). At the other end of the continuum, the citizens of OECD (Organization for Economic Cooperation and Development) societies profit from an affluence of individual resources and their prevailing values are characterized by a stronger emphasis on human emancipation. These citizens are usually governed by democratic regimes in which freedom rights are effectively set in practice. Overall, societal levels of individual resources, emancipative values and effective democracy tend to correspond to each other, as is shown in Figures 1 and 2 (see pp. 368-369).

This insight is not new. In fact, it is conventional wisdom of classical modernization theory (see Lerner 1958; Lipset 1959; Coleman 1968; Pye 1990; Diamond 1992). What is new, is the empirical evidence that has been added in recent years. Thanks to the World Values Surveys, this applies in particular to the role of value change (Inglehart 1997; Inglehart \& Baker 2000). Nevertheless, we still lack an integrated theory of social change. Modernization theorists have argued that there are close relations between socioeconomic development, emancipative values and degrees of democracy, but they did not sharpen the common focus of these three phenomena. 'Modernization' was either used as an umbrella term that was defined by enumerating its concrete components but not by what integrates them (e.g., Lerner 1968: 385); or it was described in such general terms as 'functional differentiation' (Mouzelis 1999), allowing one to subsume almost anything under 'modernization'. In conclusion, there is no general definition of modernization that clarifies in which common principle its various components converge.

Empirical studies reflect this lack of conceptual integration. Most analyses focus on only one of the three relationships between socioeconomic development, value change and democracy. Even the few studies that deal with all three processes dissolve the whole complex into single pairs of relations, each of which is discussed in separation (Muller \& Seligson 1994; Inglehart 1997; Sides 1999; Inglehart \& Baker 2000). As a result, the debate is fragmented into three separate strings.

First, following Lipset (1959), various authors claimed that socioeconomic development helps to establish or sustain democracy (among others, Cutright 1963; Bollen \& Jackman 1985; Lipset et al. 1993; Helliwell 1993; Burkhart \& Lewis-Beck 1994; Barro 1997; Vanhanen 1997; Gasiorowski \& Power 1998); while others argue that democracy promotes political stability, provides better economic policies and thus is conducive to socioeconomic development (Ersson \& Lane 1996; Rowen 1996; Leblang 1997; Feng 1997; Frey \& AlRoumi 1999; Olson et al. 2000). Second, some observers maintain that socioeconomic development gives rise to 'modern' values (Inkeles \& Smith 1974; 
Inkeles 1983; Flanagan 1987; Inglehart \& Baker 2000), but others insist that 'modern' values accelerate socioeconomic development (Putnam 1993; Fukuyama 1995; Knack \& Keefer 1997; Landes 1998). And, third, while some analysts suggest that democracy helps to produce 'civic' values (Rustow 1970; Muller \& Seligson 1994; Jackman \& Miller 1998), others claim the contrary: emerging 'civic' values put political elites under popular pressure to institutionalize democratic rules and to keep these rules effective (Gibson \& Duch 1994; Inglehart 1997: Chapter 5; Welzel \& Inglehart 2001; Welzel 2002a).

Summarizing these contradictions, Dahl (1998: 35) concluded that 'the exact nature of the relationship among socioeconomic modernization, democratization, and the creation of a democratic culture is almost as puzzling today as it was a quarter-century ago'. It remains puzzling because no one, as far as we know, started from the most fundamental question: 'What is the common denominator underlying socioeconomic development, emancipative value change and effective democracy?' This question is made all the more pressing by the striking coincidence of these three phenomena, as we will demonstrate. We start from this fundamental question and elaborate on the syndrome as such before we dissolve the whole complex into separate relations.

We unfold a concept based on the principle of 'human choice'. This principle is implicit in modernization theory (Lewis 1955: 9-19), but its capacity to integrate related changes in socioeconomic structure, political culture and regime institutions has not yet been fully developed. The following section unfolds the concept of 'human development' as an integrating framework. Anand and Sen (2000) introduced the term 'human development', arguing that 'human choice', or the capability of human beings to choose the lives they want, should be the ultimate measure of social progress. We share this humanistic approach, but, following Welzel (2002a), we elaborate the concept of 'human development' more comprehensively in a way that includes political culture. Using this framework, we analyze data from the World Values Surveys together with socioeconomic data from Vanhanen (1997), civil and political rights ratings from Freedom House and estimates on elite corruption from Transparency International. Subsequent sections demonstrate that the syndrome of human development operates across nations, regions and cultural zones; that this syndrome is shaped by a process in which socioeconomic development and rising emancipative mass values lead to rising levels of effective democracy; and that the effect of emancipative values on effective democracy operates through their impact on elite integrity. Indeed, elite integrity (i.e., the reverse of elite corruption) is the factor that makes formal democracy effective. 


\section{Theory}

\section{The three components of human development}

Our conception follows Welzel (2002), arguing that socioeconomic development, rising emancipative values and effective democracy work together in promoting human choice among societies (see also, Welzel \& Inglehart 2001).

Socioeconomic development includes a bundle of processes (e.g., urbanization, social mobilization and occupational differentiation) that increase social complexity and multiply social transactions between human beings (Bendix 1974; Durkheim 1988; Simmel 1984; Blau 1994). These tendencies help to emancipate people from closed in-group discipline, to weaken vertical authority relations and to strengthen horizontal bargaining relations, giving people greater autonomy over their resources. Moreover, socioeconomic development not only individualizes available resources, it also enlarges these resources: rising incomes, skills and information facilities increase people's physical and intellectual resources. Socioeconomic development diminishes the most existential constraints on human choice by increasing individual resources. These resources give people the objective means of choice. This view is as old as Aristotle and has been argued from Adam Smith and Karl Marx to Amartya Sen.

Emancipative cultural change is the second component relevant to human choice. When growing individual resources widen the scope of possible human activities, the strive for self-realization, autonomy and emancipation finds greater leverage, strengthening people's desire to have free choice and control over their lives. Rising emancipative values direct people's subjective orientations towards human choice, contributing the motives component to this theme. This is consistent with the notion that choice is not only a matter of one's means but also of one's mind and motivation (Rokeach 1960).

Democracy is the third component of human development. It is related to human choice because it institutionalizes legal rights that guarantee choices in people's private and public activity. However, it is important that these rights are not only formally guaranteed but work effectively in practice. This is what distinguishes effective democracy from formal democracy. Effective democracy contributes effective rights to human choice and thus represents its rules component. Effective democratization, in this sense, is any extension of people's effective rights. This notion can be traced back to Mill and Dewey who saw effective opportunities for 'individual self-development' (Macpherson 1977: 44-76) as the core value of democracy.

Individual resources, emancipative values and effective rights represent the means, motives and rules components of human development. These com- 
ponents are provided by socioeconomic development, emancipative value change and democratization, respectively. Table 1 summarizes this conception of human development.

The three components of Human Development all coincide in their focus on human choice. Progress in any of these components improves a society's 'conditio humana', giving people larger means, stronger motivations and more effective guarantees to make use of their personal potential. Human development of societies means growing human choice on a mass level.

Human development is not a teleological concept. It does not imply that its three components necessarily grow in a linear upward direction. Societies can move in either direction: progressing or regressing. However, our theory does imply that people's means, motivations and rights tend to develop coincidentally, either narrowing or widening the range of human choice.

The concept of 'human development' goes beyond standard modernization theory in having both a wider scope and a sharper focus. Usually, theories cannot maximize scope and focus at the same time, but the concept of 'human development' does. On the one hand, its scope is comprehensive, integrating major changes in socioeconomic structure, political culture, and regime institutions. On the other hand, this concept is sharply focused on one theme: the growth (or decline) of human choice.

Table 1. The concept of human development

\begin{tabular}{|c|c|c|c|}
\hline & \multicolumn{3}{|c|}{ Human development } \\
\hline & $\begin{array}{l}\text { Economic } \\
\text { dimension }\end{array}$ & $\begin{array}{l}\text { Cultural } \\
\text { dimension }\end{array}$ & $\begin{array}{l}\text { Institutional } \\
\text { dimension }\end{array}$ \\
\hline Components & $\begin{array}{l}\text { INDIVIDUAL } \\
\text { RESOURCES }\end{array}$ & $\begin{array}{l}\text { EMANCIPATIVE } \\
\text { vaLUES }\end{array}$ & $\begin{array}{l}\text { FREEDOM } \\
\text { RIGHTS }\end{array}$ \\
\hline Generating processes & Socioeconomic development & $\begin{array}{l}\text { Emancipative } \\
\text { cultural change }\end{array}$ & $\begin{array}{l}\text { Democratization, } \\
\text { extension of rights }\end{array}$ \\
\hline Societal spheres & $\begin{array}{l}\text { Sphere of means } \\
\text { (social structure) }\end{array}$ & $\begin{array}{l}\text { Sphere of motives } \\
\text { (political culture) }\end{array}$ & $\begin{array}{l}\text { Sphere of rules } \\
\text { (regime institutions) }\end{array}$ \\
\hline Prevailing causal direction & \multicolumn{2}{|c|}{ Means-motives linkage } & rules linkage \\
\hline Underlying theme & \multicolumn{3}{|c|}{ Human choice on a mass level } \\
\hline
\end{tabular}


We suggest that the human development syndrome is shaped by two linkages: a means-motives linkage that connects emancipative values with individual resources, and a motives-rules linkage that ties effective rights to emancipative values.

The Means-Motives Linkage: A public's prevailing value orientations reflect the constraints imposed on human autonomy by more or less pressing social conditions. These constraints are most existential and pressing in the socioeconomic sphere, when scarce resources deprive people of many options in their life. Usually, people tend to adapt their aspirations to these constraints (Schwartz 1992; Diener et al. 1995; Cummins 2000; Eckersley 2000; Schmuck et al. 2000). This mechanism - known in social psychology as 'aspiration adjustment' (Costa et al. 1987) - has emerged through human evolution because it secured survival (Birch \& Cobb 1981; Doyal \& Gough 1991; Tooby \& Cosmides 1992). Aspiration adjustment leads people to aspire for the most pressing things first and to avoid wasting energy on unattainable goals (Maslow 1988). Downward adjustment of aspirations works against the higher-ordered human strives, in particular for self-expression. Striving for self-expression requires freedom and choice, and cannot unfold under pressing social constraints. Yet, the striving for self-expression is latent in each person: it follows from the simple fact that human beings are self-conscious. This insight led many theorists - including Marx, Maslow, Inkeles and Flanagan - to the conclusion that less pressing and more permissive social conditions (which offer greater choice) create greater satisfaction and fulfillment. Indeed, data from the World Values Surveys support the view that greater human choice increases individual life satisfaction. In each of 148 national representative surveys, conducted in such diverse societies as Uganda, China, Iran, Brazil, Sweden or Poland, there is a highly significant correlation between people's life satisfaction and their perception of how much choice they have in shaping their live. ${ }^{1}$

If pressing social conditions restrict human choice, people are forced to reduce their actual emphasis on self-expression, although this downward adjustment of aspirations has psychological costs in that it diminishes life satisfaction. Downward adjustment of aspirations is nevertheless necessary to make a living under pressing human conditions, such as those prevailing in poor societies where scarce resources drive people into a struggle for survival. Survival strategies may constitute a Hobbesian 'homo homini lupo' situation in which outsiders are distrusted as hostile competitors for scarce resources. Distrust towards outsiders forces individuals into rigid in-group discipline 
that leaves little room for human autonomy. Banfield (1958) examined the Southern Italian community of Montegrano to describe such a typical survival situation. Putnam (1993) reaches similar conclusions in his description of differences between Italian citizens of the affluent North and the poor South, finding that Southern Italians distrust their fellow citizens. These citizens tend to place emphasis on group discipline, social control, hierarchy, moral rigidity and strong authority - conformity values that prevail under restrictive human conditions.

Inglehart (1997) demonstrated for a much wider array of countries that the public's suffering from scarce resources tend to be dominated by conformity values. Similarly, societies whose people dispose of more individual resources place stronger emphasis on emancipative values. This reflects the fact that the benefits of conformity values recede when existential constraints on human choice fade. Accordingly, conformity values tend to give way to emancipative values, which is reflected in greater tolerance of human diversity, higher life satisfaction and stronger emphasis on individual freedom. According to Flanagan (1987), this value change reflects a functional mechanism of aspiration adjustment at the societal level.

The Motives-Rules Linkage: Living an emancipated life involves activities, both private and public, that require a legal space based on effective freedom rights. Emancipative orientations are therefore inherently directed towards effective rights. So, if emancipative orientations gain momentum among the broader public, their directedness towards effective rights should be consequential for the stability of political regimes.

If growing individual resources give rise to emancipative orientations within an autocracy, people will consider authoritarian rule as an illegitimate restriction of their rights. Confronted with an elite unwilling to democratize, these people will withdraw as much material and moral support as they can. This makes authoritarian rule increasingly ineffective and costly. The exhaustion of a regime's resources and the loss of legitimacy make two events more likely: that a faction of the elite splits off in an attempt to regain legitimacy by mobilizing popular support for liberal reforms (Przeworski 1992), and that democratic dissidents campaign for holding free elections (see Foweraker \& Landman 1997; McAdam et al. 2001: Chapter 9). Depending on the strength and spread of emancipative orientations, the mobilization of the public will then be channeled in the direction of democratization, helping to terminate an authoritarian regime and to establish freedom rights.

If emancipative orientations grow in a democracy, the likely result is not regime change but an increasing effectiveness of given freedom rights. A society may be organized as a formal democracy such that all the basic freedom rights are legally guaranteed, but legal guarantees do not necessarily 
make these rights effective. Even a democracy can be ruled by corrupt elites who deprive the citizens of their rights. In a poor society that is dominated by conformity values, most citizens have neither the resources nor the motivation to form effective popular pressure such that the elites feel urged to respect people's rights. However, in a society in which emancipative values are more strongly pronounced, people will be more willing to exert public pressure to keep the elites accountable. Usually, these citizens also dispose of the resources to make their pressure effective. As noted by Verba et al. (1978: 73), 'in all nations, citizens appear to convert socioeconomic resources into political involvement'.

In democracies, elites are recruited from the electorate. Thus, changing values among the citizens will affect the elites as well. So, if there is a shift toward emancipative values in the population, the elites also will be affected by these values. Data from the World Values Surveys support this assumption, demonstrating that people with university degrees place more emphasis on emancipation than do ordinary citizens (Welzel 2003: 278). Yet the crossnational differences in emphasis on emancipation are just as large among people with university degrees as they are among the ordinary citizens. Given that elites are overwhelmingly recruited from people with university education, this finding suggests that a public's emphasis on emancipation is well represented among its elites.

If the elites are influenced by emancipative values, they are more likely to consider corrupt behavior as an illegitimate violation of freedom rights. Thus, there are two reasons why a societal shift towards emancipative values will reduce corrupt elite behavior and increase the effectiveness of given rights. One is that the masses dispose of more resources and stronger motivations to put elites under popular pressure. The other reason is that the elites are, by their own beliefs, willing to respect people's rights. From a rational choice perspective, there is no reason to expect that elites avoid maximizing their benefits through corruption, unless their own values or popular pressure eliminate this option from rational calculation.

Consider now the reverse relation: Can freedom rights by their mere presence create emancipative values among the citizens? Our answer is 'no', unless the resources which feed these values are present. For example, consider India: though offering its citizens a wide array of freedom rights during 50 years of formal democracy, most Indians did not develop a correspondingly strong emphasis on human emancipation (as is demonstrated by India's location in Figures 1A and 2A). On the other hand, former Czechoslovakia provided its citizens with much narrower freedom rights under four decades of communist rule, but the Czechs (and, to a lesser degree, the Slovaks) developed much stronger emphasis on emancipation than most of the Indians did - in keeping 
with their greater material and intellectual resources (see again Figure 1A). This does not mean that formal democracy cannot exist without corresponding emancipative values. Actually it can, as the Indian example shows. Yet, if so, formal democracy is likely to be ineffective. To be practiced effectively, formal rights need corresponding values, but cannot create them. Formal rights are only an institutional offer that cannot by itself create the demands that make it effective. In conclusion, effective democracy is the consequence rather than the cause of emancipative mass values.

\section{Formal democracy and effective democracy}

The Indian case illustrates how important it is to differentiate between formal democracy and effective democracy. India is without doubt a formal democracy that guarantees its citizens a wide array of freedom rights, but as Heller has pointed out (2001), most Indians do not have the resources enabling them to exert their rights effectively. They also do not place so much emphasis on emancipation that they are willing to insist on fully practicing their rights. In terms of effective democracy, India ranks closer to China than to Japan (see Figure 2A), although India has a democratic constitution.

Democracy is central to human development because it gives the citizens formal rights. Codifying these rights creates formal democracy, which is a necessary component of effective democracy: without formal democracy there can be no effective democracy. Yet formal rights are not sufficient to make democracy effective. Formal rights are effective to the extent that the elites respect these rights in their actual behavior. Law-abiding elite behavior, or what we call 'elite integrity', is an expression of the 'rule of law' that, as Linz and Stepan (1996) and many others have claimed, distinguishes effective democracy from formal democracy. Hence, in order to measure effective democracy, we weigh formal democracy by elite integrity, using elite integrity as a grading factor that either downgrades or upgrades given levels of formal democracy.

\section{The mass-system linkage in human development}

Our theory of human development maintains that effective democracy is linked to emancipative mass values and that these values are in turn linked to people's available resources. However, while the linkage between effective democracy and emancipative values becomes manifest only at the societal level, the linkage between emancipative values and available resources originates at the individual level from where it simply accumulates to the societal level. This accumulation reflects mass tendencies that are important to understand the mass-system linkage in human development. 
Evidence that the linkage between available resources and emancipative values originates at the individual level is given by the fact that individuals with more resources show a significantly stronger emphasis on emancipation (see the section on data sources and measurement below for a description of these variables): within each of 112 opinion polls from the World Values Surveys there is a significantly positive correlation between individuals' emphasis on emancipation and their income and education. On average, these individual-level correlations within nations point to $r=0.29$ (standard deviation: 0.08$){ }^{2}$ Yet compared to the societal level, where we measure a 0.91 correlation, the correlation is relatively weak at the individual level within nations. Why this is so can be explained by gravity effects, reflecting mass tendencies within populations.

National communities are held together by institutions that socialize citizens into common traditions. Accordingly, nations tend to create distinguished 'central tendencies' among their citizens' prevailing values. Thus, there is larger variance in value orientations between citizens of different nations than between those of the same nations. Of course, emphasis on emancipation varies considerably between individuals within nations. Yet, within each nation a majority of the individuals cluster near their nation's mean emphasis on emancipation. In other words, most people's emphasis on emancipation is close to the average citizen's emphasis. However, these averages vary enormously from nation to nation (see Figure $2 \mathrm{~A}$ on p. 369). In fact, the national averages in emphasis on emancipation capture fully 40 per cent of the total individual-level variance among all people ever surveyed in four waves of the World Values Surveys. This is a remarkable proportion, with only 73 national units accounting for nearly half of the variance among 158,802 individuals (this is more than 2,000 times the random likelihood).

The relevance of nations' mass tendencies becomes evident when one recognizes another regularity in social sciences: variations in an independent variable $x$ do never perfectly translate into corresponding variations of a dependent variable $y$. All known relationships in social reality are probabilistic, showing a 'range of uncertainty' within which variations in $x$ are not reflected in corresponding variations in $y$ (Inglehart \& Welzel 2003). Only large variations in $x$ that exceed this uncertainty range are reflected in corresponding variations of $y$.

From this point of view, consider the relation between available resources and emancipative values and assume that both variables show relatively concentrated distributions within nations. This implies that only a minority of individuals deviates largely from the national averages in both variables. In other words, the majority of individuals is bound in the uncertainty range within which variations in available resources are not reflected in corresponding 
variations in emancipative values, which necessarily produces a small individual-level correlation within nations. Yet across nations, most individuals' resources deviate so largely from the global mean that they exceed the range beyond which corresponding deviations in emancipative values occur. In this case, the individual-level correlation is stronger across than within nations. Therefore, it is important to take cross-national variation into account: this makes individual-level relations visible that are otherwise hidden by the nations' mass tendencies.

The nations' mass tendencies are reproduced through social processes that affect national populations uniformly but to degrees that vary largely between them. The growth of individual resources is a typical process of this kind. Germany is one among many examples where most people's financial income is close to the average national income. This was so 40 years ago and it is still so today. However, during these 40 years the average individual income has quadrupled, with little effect on the distribution of incomes (Zapf \& Habich 1999). Hence, income growth is a process that affects national populations rather uniformly, although this process varies enormously between nations. As noted by Landes (1998: xx), 200 years ago the income ratio of the richest to the poorest nations was approximately $5: 1$. Uneven economic growth has dramatically raised this ratio to 400:1 today. Thus, economic development moves through nations in a way that reproduces their central tendencies to a considerable degree, while it creates much greater disparity between them. As a consequence, any effect connected to growing individual resources, such as rising emancipative values, must be more pronounced between than within nations.

If two related variables show distributions that are concentrated within and divergent between nations, the individual-level correlation must be stronger across than within nations. Across nations, the correlation becomes even stronger when the respective variables are averaged to the nation level. The reason of this regular phenomenon is that aggregation eliminates random variations at the individual level. Survey data usually contain much random variation due to measurement error: many respondents give erratic answers that reflect 'non-attitudes', producing a good deal of random noise at the individual level (Converse 1970). These measurement errors increase the random terms in correlations, which produces small correlations at the individual level (Yule \& Kendall 1950; Blalock 1961). However, since measurement errors are largely random, one can reduce these errors through aggregation. Averaging individual-level data to the nation level diminishes measurement error because random deviations to the left and right of a national mean simply cancel each other out (Page \& Shapiro 1993: 40). Consequently, the random 
term of a correlation becomes smaller and the correlation as such becomes larger through aggregation. In the presence of random measurement error, aggregation does not obscure but reveals the 'real' correlation.

Another question refers to the essential meaning of aggregate data, such as a nation's average emphasis on emancipation. Is this average a real community characteristic? Of course, this average is calculated from each individual's responses. Yet, for each individual the average reflects to practically 100 per cent the responses of all other individuals. Thus, aggregate figures represent mass tendencies that are almost perfectly exogenous to the individuals from which they are calculated. It is therefore not mistaken to consider a nation's average emancipative orientation as a feature of this nation. The nation level is the level at which emancipative orientations get linked with democracy.

The linkage between emancipative mass values and effective democracy reflects a relation between two different sorts of societal characteristics. Emancipative values represent an aggregated mass characteristic that accumulates from the individual level. By contrast, effective democracy is a genuine system characteristic that does not exist at the individual level. Yet the difference between mass characteristics and system characteristics does not invalidate the question of their relationship. Quite the contrary, this question is at the heart of democratic theory because democratic theory is interested in the relationship between the citizens and their political regimes. In this sense, democratic theory searches for the mass-system linkage. If such a mass-system linkage should exist, it must be reflected in the relation between a mass variable, such as emancipative values, and a system variable, such as effective democracy. Human development theory focuses on precisely this linkage.

\section{Analyses}

\section{Data sources and measurement}

In order to measure emancipative values, we use the largest available data set - the European/World Values Surveys (EVS/WVS), which cover 73 countries representing 80 per cent of the world's population. ${ }^{3}$ We measure emancipative values using a scale of factor scores summarizing several attitudes that Inglehart and Baker (2000) have proposed as indicators of self-expression values. We replicate their analyses using for the first time all four waves of the EVS/WVS conducted between 1981 and 2001. The results are reported in Table 2. 
Table 2. The composition of emancipative values

\begin{tabular}{|c|c|c|c|}
\hline \multirow[b]{2}{*}{ Variables } & \multicolumn{3}{|l|}{ Levels of analysis } \\
\hline & $\begin{array}{l}\text { Individual level } \\
\text { within nations } \\
\text { (mean loadings) }\end{array}$ & $\begin{array}{l}\text { Individual level } \\
\text { across nations } \\
\text { (pooled loadings) }\end{array}$ & $\begin{array}{l}\text { Aggregate } \\
\text { cross-national } \\
\text { level }\end{array}$ \\
\hline \multicolumn{4}{|l|}{$\begin{array}{l}\text { Strong emancipative values } \\
\text { imply: }\end{array}$} \\
\hline Tolerance of human diversity ${ }^{1}$ & 0.47 & 0.68 & 0.82 \\
\hline Inclination to civic protest ${ }^{2}$ & 0.45 & 0.65 & 0.87 \\
\hline Liberty aspirations $^{3}$ & 0.54 & 0.59 & 0.82 \\
\hline Trust in people ${ }^{4}$ & 0.34 & 0.47 & 0.64 \\
\hline High life satisfaction $^{5}$ & 0.13 & 0.44 & 0.76 \\
\hline Weak religiousness ${ }^{6}$ & -0.29 & -0.37 & -0.41 \\
\hline \multicolumn{4}{|l|}{$\begin{array}{l}\text { Weak emancipative values } \\
\text { imply the opposite. }\end{array}$} \\
\hline Explained variance & $23 \%$ & $29 \%$ & $54 \%$ \\
\hline Number of cases & $\begin{array}{l}137 \\
\text { national surveys }\end{array}$ & $\begin{array}{l}158,803 \\
\text { individuals }\end{array}$ & $\begin{array}{l}137 \\
\text { nation per } \\
\text { wave units }\end{array}$ \\
\hline \multicolumn{4}{|c|}{$\begin{array}{l}\text { Notes: Entries are factor loadings. Explorative principal components analysis (extraction } \\
\text { of factors with 'Eigenvalues' above } 1 \text { adviced), no rotation. ' 'Not mentioned' for 'disliked } \\
\text { neighbors' coded ' } 1 \text { ' and dichotomized against ' } 0 \text { '; scores added for neighbors with AIDS } \\
\text { (V58) and homosexual neighbors (V60). Aggregate data are national averages on this } 0-2 \\
\text { scale. 'Already done' for 'signing petitions' (V118) coded ' } 1 \text { ' and dichotomized against ' } 0 \text { '. } \\
\text { Aggregate data are national percentages already done. }{ }^{2} \text { Respondents' first and second } \\
\text { priorities for 'giving people more say in important government decisions' and 'protecting } \\
\text { freedom of speech' (V106-107) added to a four-point index, assigning } 3 \text { points for both items } \\
\text { on first and second rank, } 2 \text { points for one of these items on first rank, } 1 \text { point for one of } \\
\text { these items on second rank and } 0 \text { for none of these items on first or second rank. Aggre- } \\
\text { gate data are national averages on this } 0-3 \text { scale. }{ }^{4} \text { Respondents believing 'most people can } \\
\text { be trusted' (V27) dichotomized as ' } 1 \text { ' against ' } 0 \text { '. Aggregate data are national percentages } \\
\text { of people trusting. }{ }^{5} 10 \text {-point rating scale for life satisfaction (V65). Aggregate data are } \\
\text { national averages on this } 1-10 \text { scale. ' 'How important is God in your life?' (V190). } 10 \text {-point } \\
\text { scale (' } 1 \text { ': not at all, ' } 10 \text { ': very important). Aggregate data are national averages on this } 1-10 \\
\text { scale. }\end{array}$} \\
\hline
\end{tabular}

Source: European/World Values Surveys I-IV, available online at http://wvs.isr.umich.edu. 
The logic of emancipative values points to what Rawls (1993) calls a 'rational sense of reciprocity': emancipated people who have self-respect and emphasize their liberty also have strong respect for the liberty of their fellow citizens. In a way, it is natural that people who emphasize their own liberty respect other people's liberty as well. Emancipative values, in this sense, reflect the logic and the experience of mutual human exchange, which rests on giving and taking: people tend to treat their peers like they have been and want to be treated by them (Axelrod 1983). Thus, emancipative values not only include an 'ego-emphasizing' attitude, reflected in liberty aspirations ${ }^{4}$ and an inclination to protest activities (such as signing petitions) , $^{5}$ but also an attitude of openness towards 'alter-ego', as reflected in tolerance of human diversity and interpersonal trust (see the notes to Table 2 for the operationalization of these variables). Moreover, emancipative values are linked with greater life satisfaction, which implies that striving for freedom, autonomy and emancipation is embedded in human motivation, leading to greater satisfaction and fulfillment. Finally, as a typical conformity value, strong religiousness is negatively linked with emancipative values.

As expected, factor loadings increase systematically from the individual level within nations to the pooled individual level to the aggregate level across nations. The reasons were explicated in the previous section: first, there are pronounced mass tendencies within nations that bound individual value orientations into a relatively small range. Individual-level variations within this range are to a large degree random. Thus, the linkage between individual-level attitudes is not so clearly structured within nations: hence, the smallest factor loadings at the individual level within nations. Second, variations in mass tendencies between national populations are more pronounced and less random than individual-level variations within nations. Therefore, taking cross-national variation into account by pooling individual-level data brings the linkage between individual-level attitudes more clearly to the fore: hence, the factor loadings are larger at the pooled individual level than at the individual level within nations. Finally, there are still measurement errors at the individual level. Averaging the data to the national level eliminates these errors, making the linkage between mass attitudes even more evident: hence, the strongest factor loadings occur at the aggregate level.

In subsequent analyses, we examine emancipative mass values that are measured in either the early or the mid-1990s. In order to keep the number of observations as large as possible, we replaced measures of the early 1990s with those of the mid-1990s when the former were not available (or vice versa). The Appendix gives a detailed description of these procedures. Pooling value orientations from slightly different points of time is unproblematic because value change proceeds slowly. Accordingly, a public's emancipative 
orientation at one point in time is highly indicative for its orientation at a slightly earlier or later point in time. Indeed, the predictive quality of emancipative values in the early 1990s for emancipative values in the mid-1990s (or vice versa) is above 90 per cent. Not making use of this strong relationship would be a waste of information.

The means component of human development - individual resources - is measured using Vanhanen's (1997) 'index of power resources'. This index combines aggregate measures of physical and intellectual resources, and a measure of social complexity. We use Vanhanen's most recent version of this index that captures the early 1990 s. $^{6}$ This measure is preferable to single indicators such as per capita GDP (gross domestic product). The use of GDP has been criticized for good reasons. Anand and Sen (2000) have argued that per capita GDP is an incomplete measure of a society's human resources. Moreover, GDP does not include the distribution of resources, although from the viewpoint of democratic theory (Dahl 1973: Chapter 4; Muller 1997), a relatively equal distribution of resources is a crucial precondition for the functioning of democracy. Finally, social complexity (which is important for the individualization of resources) is also not tapped by GDP.

For these reasons, the Human Development Index has been constructed to provide a more complete measure of individual resources (United Nations Development Program 2000). However, this index has its own limitations. One of its three components - life expectancy - does not measure individual resources at all. By contrast, the Vanhanen index captures individual resources in all aspects that are relevant to our theory of human development. It measures both physical and intellectual resources, and it measures not only levels but also the distribution of these resources. Finally, it includes a measure of social complexity. In the theoretical perspective of human development, this is the most appropriate index to measure individual resources.

The institutional component of human development - effective democracy - is measured using the Freedom House scores for civil and political rights and estimates from Transparency International on elite corruption. ${ }^{7}$ The scores from Freedom House range from 1 to 7 on both the civil and the political rights scales, with 1 indicating the highest and 7 the lowest level of freedom. ${ }^{8}$ We added scores on these scales for 1999 and 2000. Then we reversed the resulting scores so that higher figures indicate a broader scope of freedom rights. Finally, we equaled the highest possible score (28) with 100 and standardized all other scores on this value. This allows an interpretation in percentages: a score of 75 indicates that a country reaches 75 per cent of the possible maximum in freedom rights. The scores from Freedom House are expert judgments that estimate the scope of given rights. We interpret these 
estimates as a measure of formal democracy, which is a necessary but insufficient element of effective democracy.

The Freedom House scores are imperfect measures of freedom rights. They neglect the extent to which given rights are respected by actual elite behavior. In order to measure how much given rights are respected by a society's office holders, we use the corruption perception scores from Transparency International. ${ }^{9}$ These scores, too, reflect expert judgments, estimating how corrupt the political, bureaucratic and economic office holders of a country behave. Corruption is a reasonable indicator for the effectiveness of people's rights, showing how far private and public services are provided on the basis of bribes instead of rights. Basing services on bribes always means a violation of the rule of law and that people are deprived of their rights: if bribery governs the provision of services, people do not obtain what they are legally entitled to obtain (see Rose 2001 for a similar argument). The corruption perception scores for 1999-2000 range from 0 to 10, with 0 indicating complete corruption and 10 indicating an absence of corruption among office holders. Positively coined, this index provides a measure of 'elite integrity', reflecting how strictly office holders abstain from corruption and follow the law. We transformed this index standardizing it to a maximum of 1.0.

As argued in the previous section, we operationalize effective democracy as the interaction between formal democracy and elite integrity, multiplying formal democracy ( 0 to 100 scale) with elite integrity ( 0 to 1 scale):

\begin{tabular}{|c|c|c|}
\hline$E \mathrm{ff}$ & & Elite \\
\hline $\begin{array}{l}\text { Democracy }{ }_{1999-2000} \\
(0 \text { to } 100 \text { scale })\end{array}$ & $\begin{array}{l}\text { Democracy }_{1999-2000} \\
\text { (0 to } 100 \text { scale) }\end{array}$ & $\begin{array}{l}\text { Integrity }{ }_{1999-2000} \\
(0 \text { to } 1.0 \text { scale })\end{array}$ \\
\hline
\end{tabular}

In this equation, elite integrity is the weighing factor that grades formal democracy, making it more or less effective. Since elite integrity operates as a grading factor, it cannot compensate for a low level of formal democracy: even a maximum elite integrity of 1.0 cannot do more than reproduce the level of formal democracy that is given. As has been shown in a two-dimensional plot (Welzel 2003: 287), to reach a high score in effective democracy is much less easy than obtaining a high score in formal democracy.

In summary, we have measures of the spread of individual resources, the strength of emancipative values and the degree of effective democracy in societies. These measures refer to different points in time and are obtained from completely different sources. Given that these measures are imperfect and may have considerable measurement error, any systematic relationship 
between them points all the more to the conclusion that they capture some robust aspect of reality.

\section{Operationalizing cultural zones}

In order to test the general applicability of human development theory, one question must be answered: 'Are the two linkages of human development universal in their presence across cultural zones?' The theory of human development can only be considered as a general theory if cultural zones are differentiated in ways that reflect the logic of human development.

Weber (1958), Eisenstadt (1986), Huntington (1996) and many others have emphasized that nations cluster into larger units labeled 'cultural zones' or 'civilizations'. Nations belonging to the same cultural zone tend to share similar worldviews, institutional traditions and patterns of economic subsistence. Thus, cultural zones can be considered as 'supra-national units of diffusion' that let nations follow similar patterns of societal development. Three variables have been considered as typical characteristics of cultural zones: historical traditions (reflected in common religious roots), imperial legacies, and region or vicinity (a spatial factor that facilitates diffusion between nations) (Kopstein \& Reilly 2000).

Each of the gray shadowed areas in Table 3 summarizes a group of nations in a distinguished cultural zone. The first criterion of this classification is religious tradition, which produces 18 countries with a historically Protestant tradition; 27 Catholic countries; 10 Christian Orthodox countries; 10 Islamic countries; and a residual category of 5 countries in the tradition of an 'Asian' religion, such as Buddhism, Hinduism or Confucianism (a quasi-religion). These five religious groups were subdivided for region or imperial legacy, if there were enough cases to allow for such a division. Thus, the Catholic countries were divided into the zones of 'Catholic Western Europe', 'Catholic Eastern Europe' and 'Latin America'. The division between Western and Eastern Europe reflects whether a country belonged to the Soviet communist empire or not. Latin America as well not only represents an own region, but is distinguished by its Iberian imperial legacy.

For some countries, specific decisions had to be made. Among the Asian countries, we saw no criterion to group China and India together with other nations. According to Huntington (1996), both of these countries, each with a population of more than one billion, represents a 'civilization' of its own. On the other hand, Japan, South Korea and Taiwan share a Confucian tradition and have in common that they are economically far advanced. Thus we summarized them as 'Developed Far East'. Moreover, Estonia and Latvia, although having a Protestant tradition, were grouped with the Catholic 
Table 3. The location of the WVS nations within cultural zones and regions

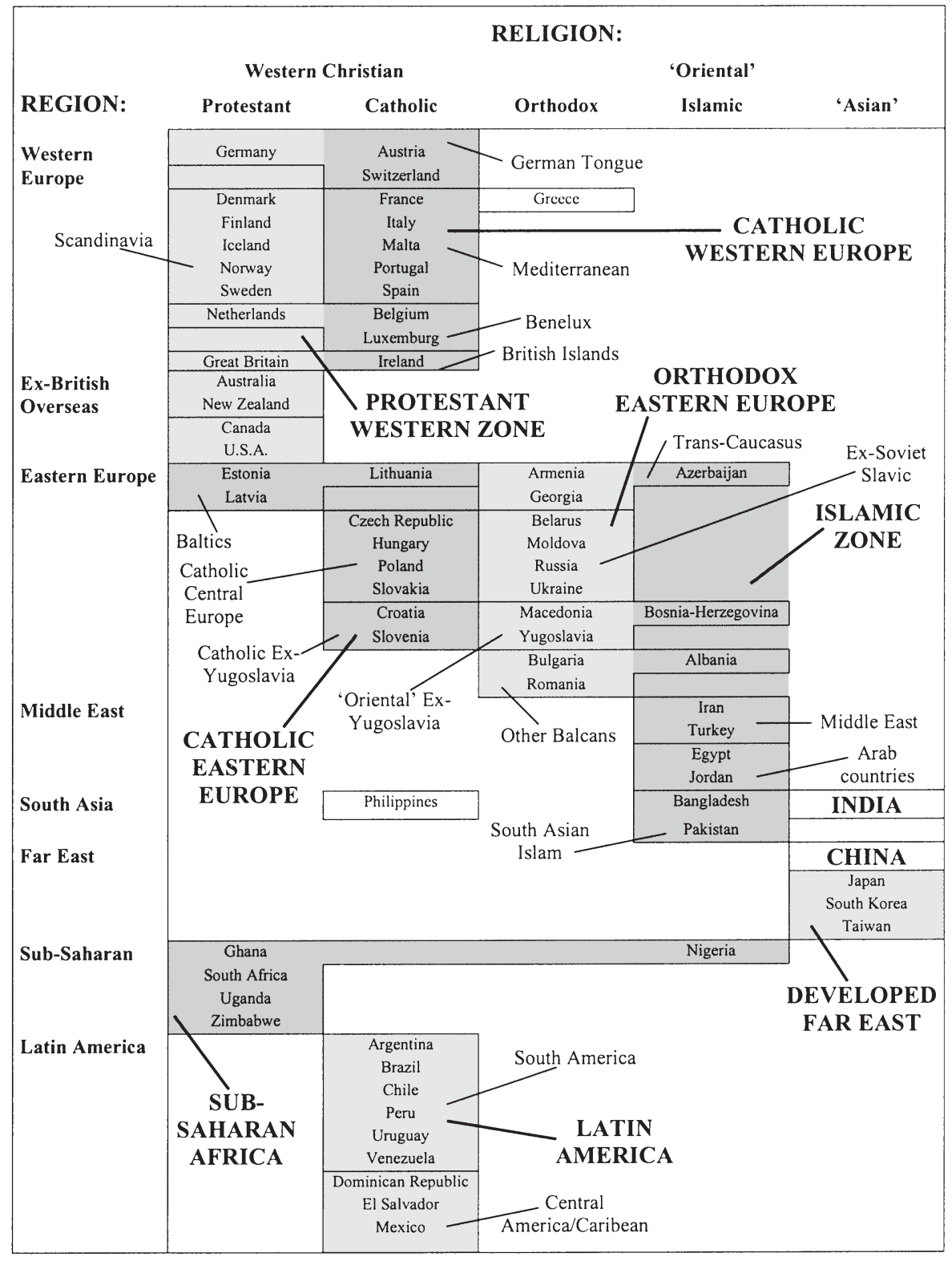


Eastern European countries with which they share the legacy of Soviet communism and the tradition of 'Western Christianity', as opposed to Orthodox Eastern Christendom (Huntington 1996: 159). Finally, the Sub-Saharan countries have not been divided on the basis of religion. Although there are Christian and Islamic influences in Sub-Saharan Africa, there remain specific Black African imprints, based on this region's animist religious roots and its distinctive ethnic make-up. This justifies classifying the Sub-Saharan countries as a specific cultural zone (Huntington 1996).

Our classification is crude. Yet, it captures respectively 85,84 and 83 per cent of the variance in individual resources, emancipative values and effective democracy across 73 nations. Even this crude classification designates relatively homogeneous zones.

In addition to this differentiation of 'cultural zones', we use a more finetuned classification based on 24 smaller 'regions', such as Scandinavia, the Baltics, Transcaucasia, Mediterranean Europe, Central America and so forth. These regions are marked by the smaller boxes in Table 3 . The regional classification captures 93, 92 and 91 per cent of the cross-national variance in individual resources, emancipative values and effective democracy. Though the classification into regions entails more than twice as many categories as the classification into cultural zones, it explains only 8 per cent more of the crossnational variance, confirming the adequacy of the cultural zones in Table 3.

\section{The human development linkages in cross-cultural perspective}

Nations, regions and cultural zones form a three-level hierarchy, with nations nested inside regions and regions inside cultural zones. From this perspective, the question is whether there are 'frictions' in the cross-level translation of the two linkages of human development: 'Do these linkages translate from the national to the regional to the cultural zone level with or without frictions?' If there are frictions, human development could not be considered as a general theory because its linkages would vary depending on the level at which they are observed. Using regression models, such frictions become evident to the extent that the intercepts and slopes of the two human development linkages vary at different levels of aggregation.

As Table 4 demonstrates, the human development linkages do not substantially vary in either their intercepts or slopes at different levels of aggregation. Whether at the national, regional or cultural zone level, intercepts and slopes remain virtually constant. The correlations, of course, increase systematically with higher levels of aggregation, indicating that random variation among lower-level units is averaged out through aggregation to higherlevel units. Yet, apart from the correlations, neither intercepts nor slopes vary 


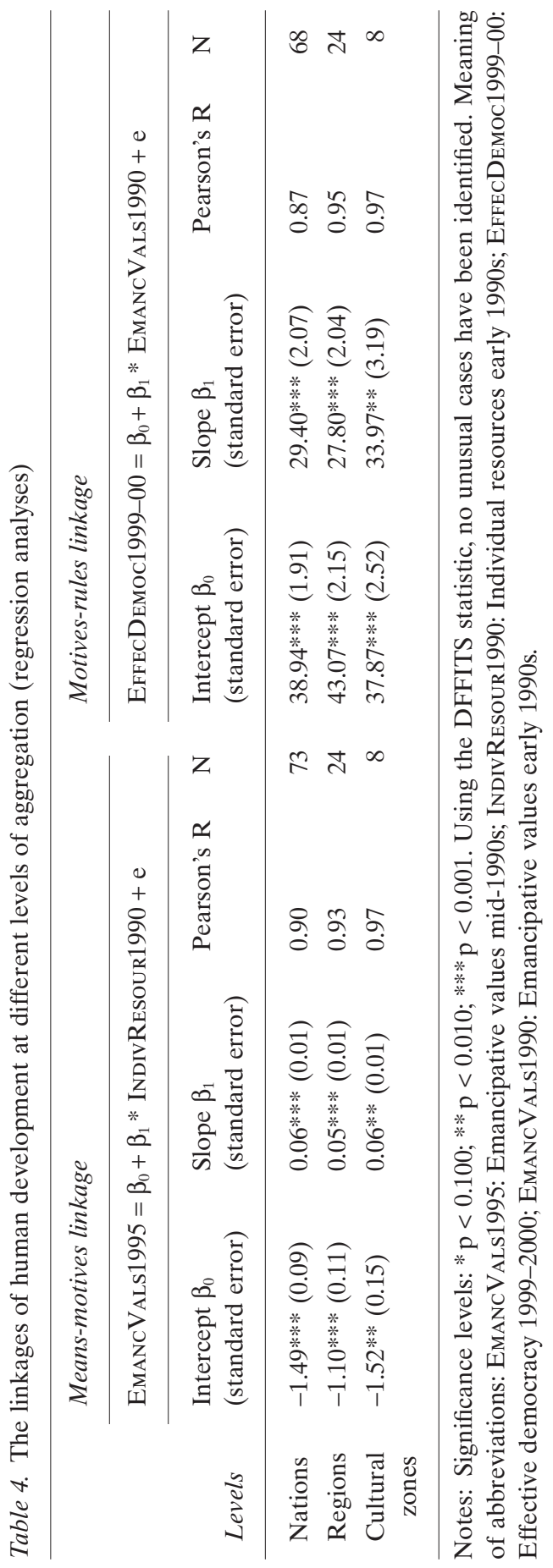


at different levels of aggregation, showing that human development translates without frictions from lower to higher levels of aggregation.

Another perspective on these results is to specify multi-level models in which we estimate overall intercepts and slopes that are constant across cultural zones, together with the intercept and slope variances for cultural zones (Goldstein et al. 1998). Thus, we formulate the relation between individual resources and emancipative values, and that between emancipative values and effective democracy in two-level models. The levels of variation are indicated with suffix ' $\mathrm{j}$ ' for the national level and suffix ' $\mathrm{k}$ ' for the cultural zone level. Allowing intercepts and slopes to vary produces a 'random intercepts/random slopes model' that is written as follows:

$$
\begin{aligned}
& \text { EmancVals1995 }_{j k}=\beta_{0 k}+\beta_{1 k} * \text { IndivResour1990 }_{j k}+e_{j k} \\
& \text { EfFecDemoc99-00 }_{j k}=\beta_{0 k}+\beta_{1 k} * \text { EmancVals1990 }_{j k}+e_{j k}
\end{aligned}
$$

We can express the composition of intercept and slope as follows:

$$
\begin{array}{ll}
\text { Intercept: } & \beta_{0 k}=\beta_{0}+u_{0 k} \\
\text { Slope: } & \beta_{1 k}=\beta_{1}+u_{1 k}
\end{array}
$$

Intercept and slope are each composed of a fixed part that is constant across cultural zones $\left(\beta_{0}, \beta_{1}\right)$ and a variable part that differs for cultural zones $\left(u_{0 k}, u_{1 k}\right)$. In addition, there is an error term for nations' remaining variation $\left(e_{j k}\right)$. This variation is random and can neither be attributed to the overall effects nor to their variation for cultural zones.

As Table 5 shows, the overall effects of both linkages are highly significant, greatly exceeding their standard errors. Hence, there exist overall effects of individual resources on emancipative values and of emancipative values on effective democracy that are independent of cultural zones. Compared to these overall effects, the cultural zone-related variances of intercepts and slopes are negligible. They do not capture significant proportions of the variance that remains unexplained by the overall effects. This can be seen by calculating the share that the intercept and slope variances have in the unexplained variance: only the intercept variance in the model explaining emancipative values captures more than 20 per cent of the random variance. However, the random variance is small because only a little variance is left unexplained by the overall effects. Hence, the intercept variance captures negligible 3.8 per cent of the total variance. Overall, the two linkages of human development show little variation for cultural zones.

Still another way to model these findings is to control the effect of individual resources on emancipative values for the cultural zone level of emancipative values. In other words, we assign to each nation its cultural zone 
Table 5. The linkages of human development in integrated multi-level models

\begin{tabular}{|c|c|c|c|}
\hline \multirow[b]{2}{*}{ Components } & & \multirow{2}{*}{ 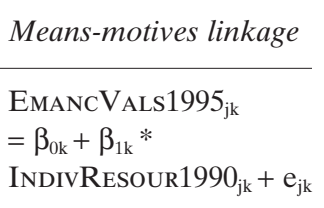 } & \multirow{2}{*}{$\begin{array}{l}\text { Motives-rules linkage } \\
\text { EFFECDEMOc1999-00 } \\
=\beta_{0 \mathrm{k}}+\beta_{1 \mathrm{k}} * \\
\text { EMANCVALS1990 } \\
\mathrm{jk}+\mathrm{e}_{\mathrm{jk}}\end{array}$} \\
\hline & & & \\
\hline $\begin{array}{l}\text { Intercept, fixed } \\
\text { component }\end{array}$ & $\beta_{0}$ & $-1.54 * * *(0.09)$ & $39.42 * * *(1.91)$ \\
\hline $\begin{array}{l}\text { Intercept variance for } \\
\text { cultural zones }\end{array}$ & $\mathrm{v}_{0 \mathrm{k}}$ & 3.12 & 297.95 \\
\hline $\begin{array}{l}\text { Slope, fixed } \\
\text { component }\end{array}$ & $\beta_{1}$ & $0.06 * * *(0.01)$ & $29.23 * * *(2.04)$ \\
\hline $\begin{array}{l}\text { Slope variance for } \\
\text { cultural zones }\end{array}$ & $\mathrm{v}_{1 \mathrm{k}}$ & 0.01 & 127.27 \\
\hline $\begin{array}{l}\text { Variance unexplained } \\
\text { by fixed effects }\end{array}$ & $e_{j k}$ & 14.17 & $15,382.66$ \\
\hline $\begin{array}{l}\text { Variance explained by } \\
\text { fixed effects }\end{array}$ & & 67.32 & $49,325.89$ \\
\hline Number of cases & & $\begin{array}{l}71 \text { nations in } 8 \\
\text { cultural zones }\end{array}$ & $\begin{array}{l}66 \text { nations in } 8 \\
\text { cultural zones }\end{array}$ \\
\hline
\end{tabular}

Notes: Meaning of suffixes: $0=$ Intercept $1=$ Slope $;=$ Nation level $; k=$ Cultural zone level. Meaning of abbreviations: EmancVals1995: Emancipative values mid-1990s; InDIvRESOUR1990: Individual resources early 1990s; EfFEcDemoc1999-00: Effective democracy 1999-2000; EmancVals1990: Eamncipative values early 1990s.

average in emancipative values and introduce this variable as an additional predictor. Thus, we test the extent to which a nation's own emphasis on emancipation is a function of the average emphasis found in its cultural zone, treating the single nations' emphasis on emancipation as a function of diffusion within cultural zones. In order to avoid a tautological measure of cultural zone diffusion, we assign each nation the mean cultural zone level calculated by excluding a given nation's own value. Hence, we specify for each nation an exogenous cultural zone effect, which is crucial for the concept of diffusion. Similarly, we estimate the effect of emancipative values on effective democracy, controlling for the cultural zone level of effective democracy.

The results of these regressions are shown in Table 6. As is evident, the effects of individual resources on emancipative values and of emancipative values on effective democracy remain highly significant across nations, even controlling for diffusion within cultural zones. This confirms our previous finding: the two linkages of human development are independent of cultural zones to a considerable degree. On the other hand, cultural zones as well show a significant impact. In fact, diffusion within cultural zones captures 30 per cent 
364 CHRISTIAN WELZEL, RONALD INGLEHART \& HANS-DIETER KLINGEMANN

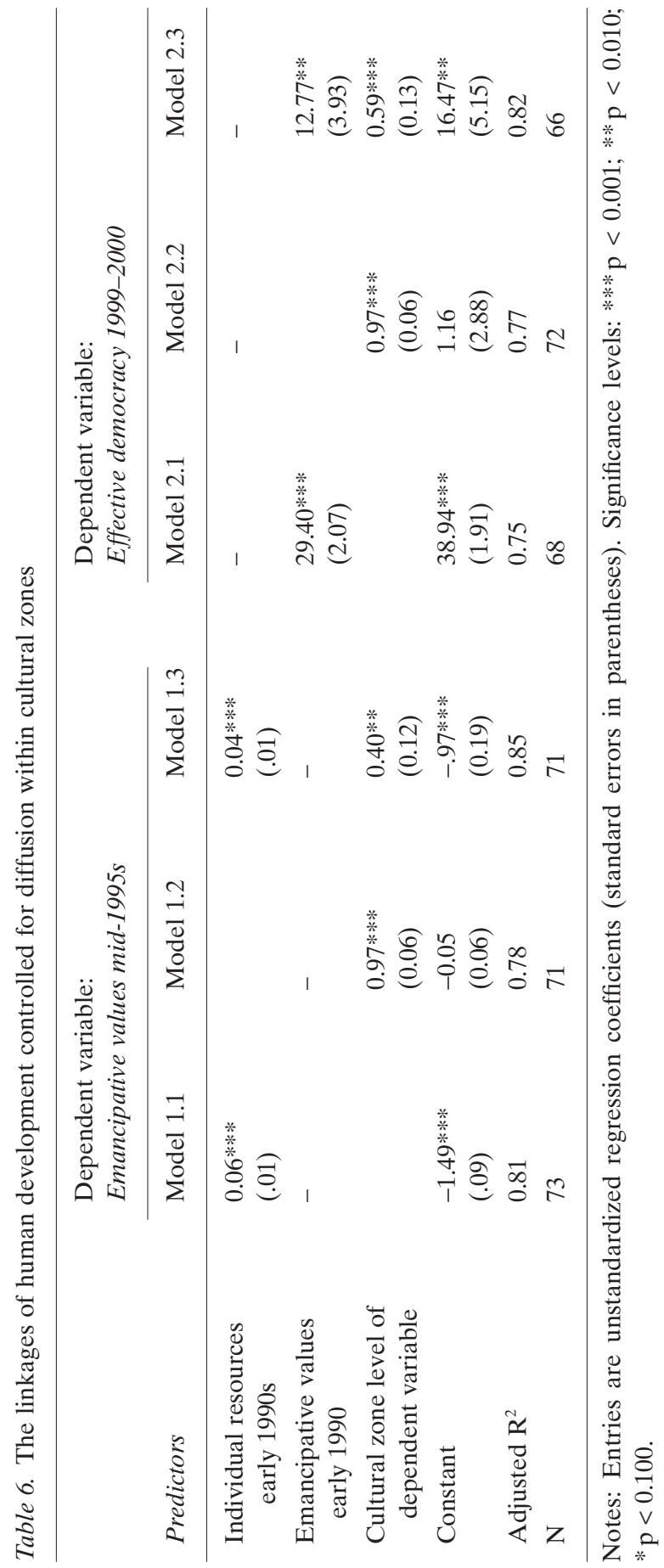


of the sole effect of individual resources on emancipative values, and 40 per cent of the effect of emancipative values on effective democracy. Why this is so, is demonstrated in Figures 1 and 2.

Figures $1 \mathrm{~A}$ and $2 \mathrm{~A}$ show the linkages of human development across nations, and Figures $1 \mathrm{~B}$ and $2 \mathrm{~B}$ across regions and cultural zones. We can see that both linkages are clearly shaped across nations, although the confidence intervals within which these linkages appear are relatively broad. This points to relatively large 'ranges of uncertainty' within which the linkages do not appear. 'Ranges of uncertainty' can be examined in the vertical dimension $(y)$ or in the horizontal dimension $(x)$. The range of uncertainty in $x$, for instance, is the horizontal distance between the left and the right boundaries of the confidence interval. This distance is constant for any value of $y$, since the confidence interval has parallel boundaries. What does this range of uncertainty mean?

Consider Figure 2A and assume you begin traveling from weaker to stronger emancipative values (i.e., from left to right) starting at any point of the left boundary of the confidence interval: as long as you travel a horizontal distance that is shorter than the 'range of uncertainty', it is not certain that the next society you meet is farther advanced in effective democracy than the previous one. Within this range, there is much random variation in effective democracy. Yet once your travel from weaker to stronger emancipative values exceeds the range of uncertainty, there is more than 95 per cent probability that the next society you meet actually is farther advanced in effective democracy. The same logic applies to the relation between individual resources and emancipative values (see Figure 1A). You must exceed a certain distance in the growth of individual resources in order to be certain that the next society you meet shows stronger emphasis on emancipation. This distance represents a threshold in the effect of individual resources on emancipative values.

Now consider Figures 1B and 2B. It is evident that the horizontal distances covered by cultural zones are so small that they hardly exceed the threshold beyond which the two linkages of human development appear. Obviously there is diffusion, clustering regions and nations into relatively homogenous cultural zones. In other words, the largest cross-national differences are between and not within cultural zones. So the decisive question is whether the linkages of human development operate across these cultural zones. Figures $1 \mathrm{~B}$ and $2 \mathrm{~B}$ leave little doubt that this is actually the case. The means-motives linkage and the motives-rules linkage do work across cultural zones. In other words, these linkages are so pronounced across nations because they operate across the units that homogenize nations.

The human development syndrome is strikingly evident at the crosscultural level. It is present there to an even higher degree than cultural zones 
homogenize nations: cultural zones capture nearly 85 per cent of the crossnational variance in each of the three components of human development, but the linkages between these components explain more than 90 per cent of the cross-cultural variation. In conclusion, the linkages of human development are not culture-specific but universal. Cultural zones differ from each other in ways that reflect the logic of human development.

\section{The genesis of human development}

According to our theory, growing individual resources on a mass level tend to shift a society's values toward greater emphasis on human emancipation. Growing mass emphasis on emancipation then channels popular pressure in the direction of effective democracy. The most debatable assumption in this argument concerns the causal relation between mass values and democratic institutions. A number of writers have claimed that the causal relation between political culture and political institutions operates into the opposite direction: only democratic institutions can produce pro-democratic values (Rustow 1970; Muller \& Seligson 1994; Jackman \& Miller 1998).

If this is correct, emancipative mass values should be the consequence of a nation's preceding democratic tradition rather than the cause of its subsequent democratic performance. This assumption can be tested. For this purpose, we specified a cross-national path model that starts from individual resources in the early 1990 s and democratic traditions up to $1995,{ }^{10}$ continues with emancipative values as of the mid-1990s and ends up with effective democracy 1999-2000. If human development theory is correct, emancipative values should have a stronger effect on subsequent democracy than prior democratic traditions have on emancipative values. If the opposite assumption is correct, the contrary should hold true.

The path model in Figure 3 supports human development theory. While democratic traditions have no effect on emancipative values, emancipative values $d o$ have a significant impact on subsequent degrees of effective democracy. This effect holds up controlling for individual resources and democratic traditions. Hence, in explaining effective democracy, the linkages of human development seem to be more important than democratic traditions, implying that growing individual resources give rise to emancipative mass values that in turn tend to promote effective democracy - even if there is a weak democratic legacy from the past.

To figure out how the impact of emancipative values on effective democracy works, we decomposed effective democracy into its components: elite integrity and formal democracy. Controlling for all other effects in the model, 


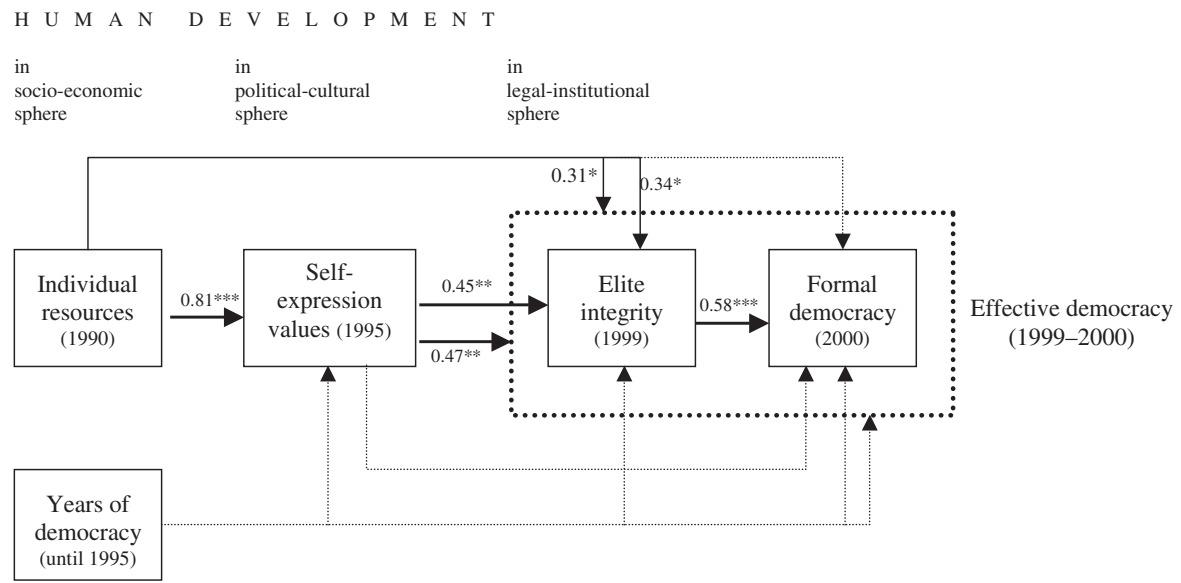

T I M E

Figure 3. Democracy as a component of human development.

Notes: Coefficients are standardized path coefficients. Bold arrows indicate strongest effect on respective dependent variable. Interrupted arrows show insignificant effects. There is no overall fit for this fully identified model. Dropping the effects of 'Years of democracy', the Adjusted Goodness of Fit Index points to 0.88 , showing that democratic tradition is negligible. Number of cases: $\mathrm{N}=68$.

elite integrity proves to be the only factor with a significant impact on formal democracy. This reflects that elites are the prime force in shaping formal democracy. Indeed, the scope of freedom rights is determined by what the elites write into the constitutions - a basic premise of the elite approach (O’Donnell \& Schmitter 1986; Higley \& Gunther 1992; Casper \& Taylor 1996). On another point, however, adherents of this approach seem to be wrong. Obviously, elite behavior is not such an independent factor as they assume. Quite the contrary, emancipative mass values have a sound effect on elite integrity. In other words, the impact of mass culture on effective democracy operates primarily through its impact on elite behavior. Mass emphasis on human emancipation tends to produce 'proper' elites who act in ways that make formal democracy effective.

There is little reason to assume a reverse causation in the relationship between emancipative values and elite integrity. Elites may have possibilities to influence public opinion in specific issues. However, such deeply rooted values as emphasis on human emancipation cannot simply be created by elite campaigns. Elites can appeal to such values but not create them. Even if they could, which interest should elites have in breeding a public that is more demanding than deferential - which the public definitely is in case of strong 


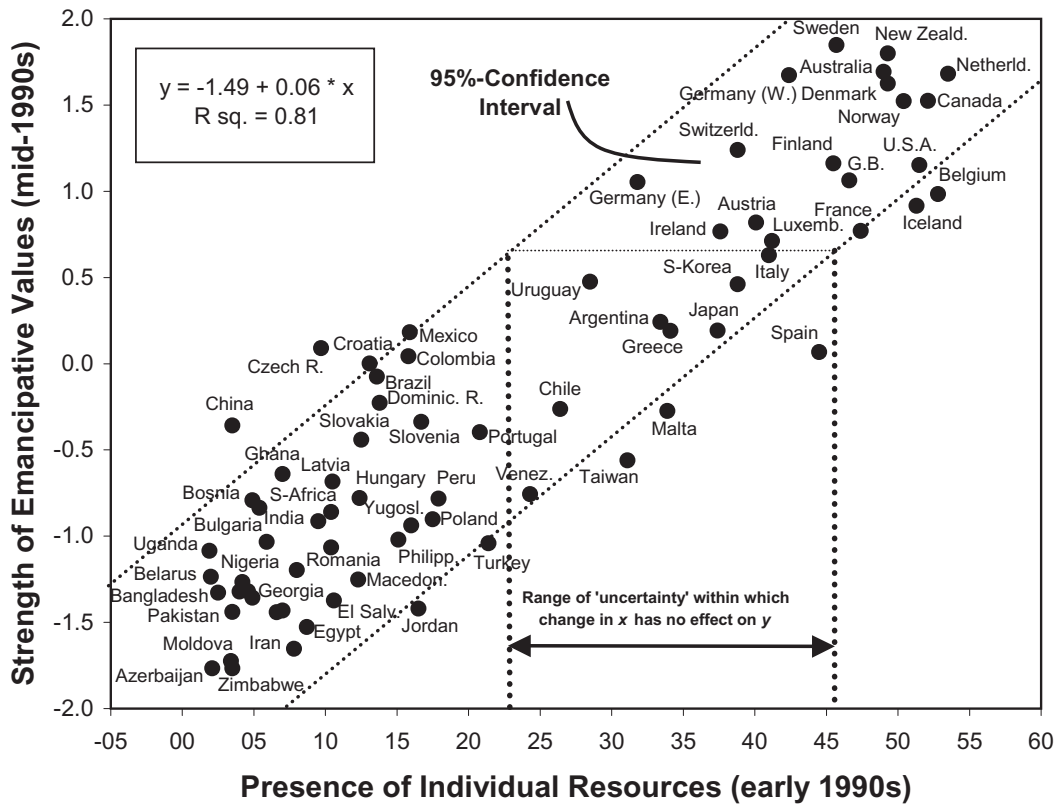

Figure 1A. The means-motives linkage across nations.

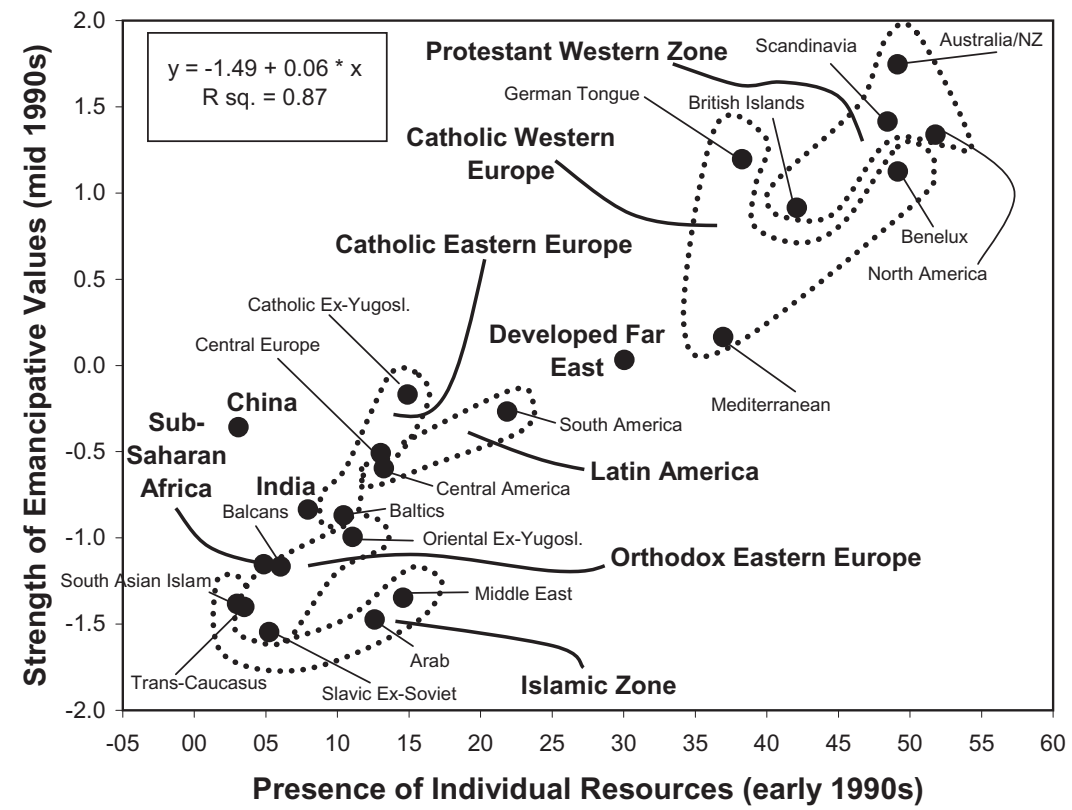

Figure $1 B$. The means-motive linkage across regions and cultural zones. 


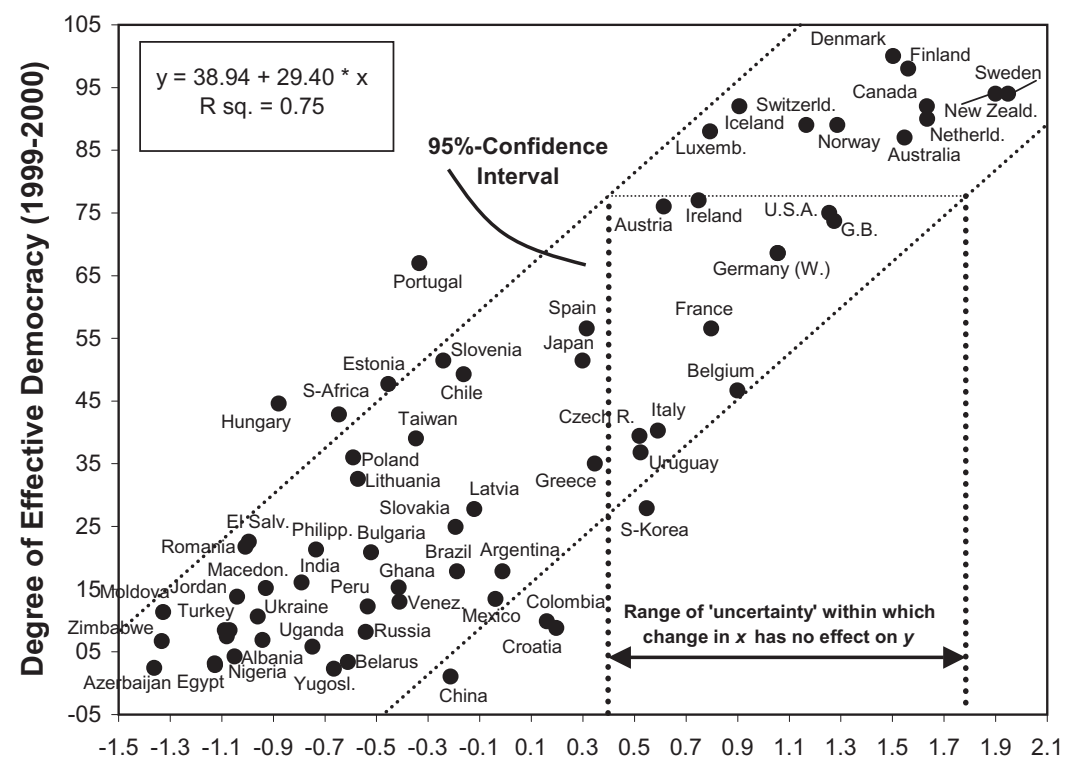

Strength of Emancipative Values (early 1990s)

Figure $2 A$. The motives-rules linkage across nations.

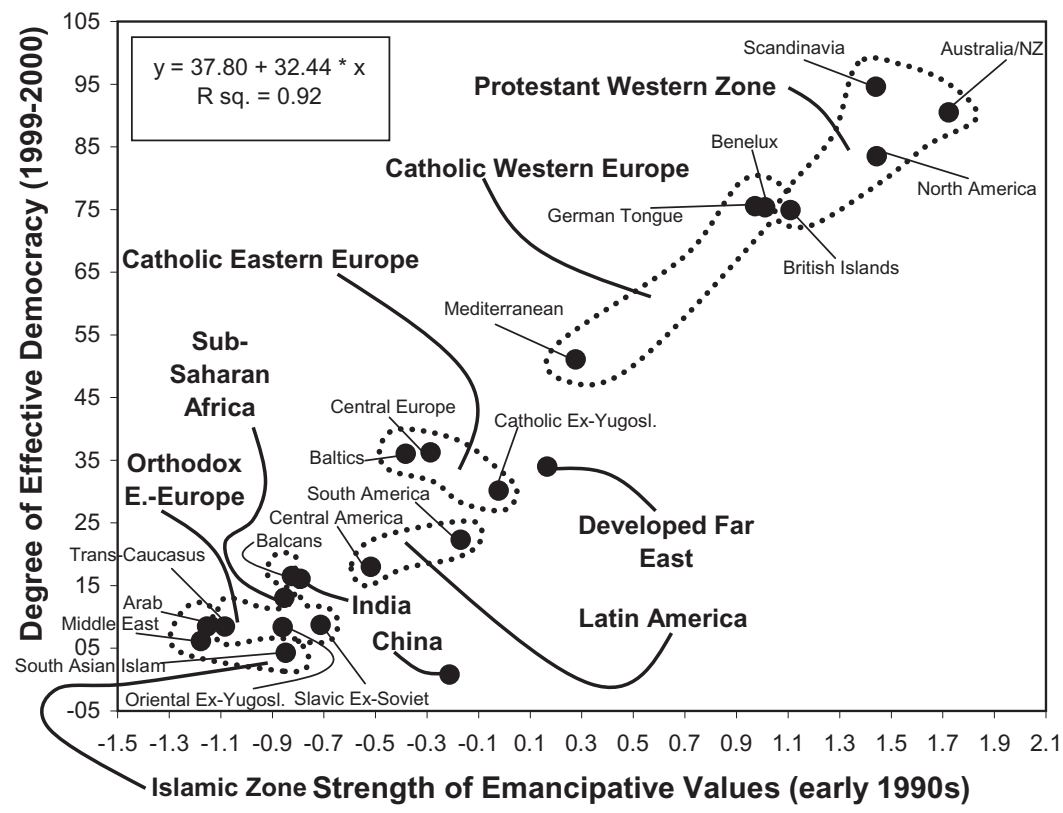

Figure $2 B$. The motives-rules linkage across regions and cultural zones. 
emancipative values. From a rational choice perspective, elites have no reason to avoid maximizing their benefits by corruption, unless there are severe restrictions on such behavior. An emancipative mass culture constitutes certainly one of the strongest of these restrictions. Such a culture either translates into powerful public pressure against corruption-seeking elites or it creates elites whose own beliefs eliminate corruption as a legitimate option. Specifying legal sanctions against breaches of the law is not enough to avoid them, if there is strong elite consensus in holding these sanctions ineffective. In conclusion, we maintain that the most plausible reading of the evidence is that mass emphasis on human emancipation increases elite integrity rather than the reverse.

\section{Conclusion}

Socioeconomic development, rising emancipative values and democratization constitute a coherent syndrome of social progress. Modernization theorists did not invest much effort to sharpen this syndrome's common focus. By contrast, the concept of 'human development', as introduced by Anand and Sen, provides a potential conception of this focus, but this potential has not been fully exploited. Thus far, the concept has neither included mass values nor elite integrity. We followed Welzel in describing human development as a targeted syndrome, arguing that the underlying theme of its three components is human choice: socioeconomic development provides people the objective means of choice; rising emancipative mass values strengthen people's subjective orientation towards choice; and formal democracy grants people the legal guarantees of choice, which are made effective by responsive elites.

Inglehart and Baker proposed a revised theory of modernization, showing that cultural zones have a significant additional impact on the effect that individual resources have on emancipative values. We go one step further here in that we add effective democracy as a third component to individual resources and emancipative values, arguing that these three components converge in a more comprehensive syndrome of human development. Furthermore, we have argued that the role of cultural zones is not one that operates against the mechanisms of human development. To be sure, diffusion within cultural zones homogenizes nations to a considerable degree, but this does not cancel the mechanisms of human development. It raises them to a higher level of operation: the way in which cultural zones differ follows the logic of human development. Thus, in cultural zones where people have larger individual resources, emphasis on human emancipation is stronger; and in cultural zones 
where emphasis on human emancipation is stronger, there is a higher degree of effective democracy.

The empirical evidence indicates that the syndrome of human development is shaped by a causal priority of individual resources and emancipative values over effective democracy. Democracy is effective only to the degree that it finds support by a mass culture that emphasizes human emancipation. Such an emancipative culture needs a socioeconomic basis that reduces existential constraints on human autonomy. Effective democracy is an evolutionary phenomenon that cannot be simply created through intelligent constitutional engineering. The emergence of effective democracy reflects changes appearing at the mass basis of societies. Effective democracy is linked to these changes by the emancipative logic of human development. Due to this logic, effective democracy improves the institutional basis of human choice.

The data we used are, of course, imperfect measures. The Vanhanen index of individual resources, the measures of emancipative values from the World Values Surveys, the freedom rights scores from Freedom House and the corruption estimates from Transparency International may all contain a considerable amount of estimation error. However, if the measurement error of these variables were large, it would be highly unlikely for one to be able to find such strong correlations as we did - unless all involved variables would be biased by the same systematic measurement error. Yet this is also highly unlikely because these variables measure clearly distinguished phenomena at different times and are taken from completely different sources. This points all the more to the conclusion that the strong linkages we found capture relevant aspects of social reality. These linkages can therefore be considered as a cross-validation of an underlying dimension - namely, human development.

\section{Acknowledgments}

We are grateful to Barry Hughes, Hanspeter Kriesi, Seymour Martin Lipset and the anonymous revewiers of EJPR for helpful comments on earlier drafts of this article.

\section{Appendix}

Aggregate measures of emancipative values have been calculated running the factor analysis shown in Table 2 across the time-pooled aggregated data set of the EVS/WVS, including 128 'nation per wave' units (not including additional regional surveys in Russia and Spain). 
Identifying emancipative values in the early 1990s

The time-pooled data matrix provides national aggregates of emancipative values from the second EVS/WVS (about 1990) for 34 countries, including: Argentina, Austria, Belarus, Belgium, Brazil, Bulgaria, Canada, Chile, China, Denmark, Germany (East), Germany (West), Finland, France, Great Britain, Hungary, Iceland, India, Ireland, Italy, Japan, Latvia, Mexico, Netherlands, Nigeria, Norway, Portugal, Russia, South Korea, Slovenia, Spain, Sweden, Turkey and the United States.

In the case of 29 countries, missing emancipative values in the second EVS/WVS have been estimated from existing emancipative values in the third EVS/WVS (about 1995). Estimates are obtained using the following regression equation (which explains 91 per cent of the variance across 21 countries): 'EmancVal1990 = $0.12+0.84 *$ EmancVal1995'. Estimates have been assigned to the following countries: Albania, Armenia, Australia, Azerbaijan, Bangladesh, Bosnia-Herzegovina, Colombia, Croatia, Czech Republic, Dominican Republic, Estonia, Georgia, Ghana, Lithuania, Macedonia, Moldova, New Zealand*, Pakistan*, Peru, Philippines, Romania, South Africa, Slovakia, Switzerland, Taiwan, Ukraine, Uruguay, Venezuela and Yugoslavia.

For another 10 countries, missing emancipative values in the second EVS/WVS have been estimated from existing emancipative values in the fourth EVS/WVS (about 2000). Estimates are obtained using the following regression equation (which explains 92 per cent of the variance across 28 countries): 'EMANCVAL1990 = $0.05+0.86 *$ EmancVAL2000'. Estimates have been assigned to the following countries: Egypt, El Salvador, Greece, Iran, Jordan*, Luxembourg, Malta, Poland, Uganda and Zimbabwe.

\section{Identifying emancipative values in the mid-1990s}

The time-pooled data matrix provides national aggregates of emancipative values from the third EVS/WVS (about 1995) for 50 countries, including: Albania, Argentina, Armenia, Australia, Azerbaijan, Bangladesh, Belarus, Bosnia-Herzegovina, Brazil, Bulgaria, Chile, Colombia, Croatia, Czech Republic, Dominican Republic, Germany (East), Germany (West), Great Britain, Estonia, Finland, Georgia, Ghana, Hungary, India, Latvia, Lithuania, Macedonia, Mexico, Moldova, New Zealand*, Nigeria, Norway, Pakistan*, Peru, Philippines, Romania, Russia, South Africa, Slovakia, Slovenia, Spain, Sweden, Switzerland, Taiwan, Turkey, the United States, Ukraine, Uruguay, Venezuela and Yugoslavia.

In the case of 13 countries, missing emancipative values in the third EVS/WVS have been estimated from existing emancipative values in the 
second EVS/WVS (about 1990). Estimates are obtained using the following regression equation (which explains 91 per cent of the variance across 21 countries): 'EmancVal1995 $=-0.13+1.08 *$ EmancVal1990'. Estimates have been assigned to the following countries: Austria, Belgium, Canada, China, Denmark, France, Iceland, Ireland, Italy, Japan, Netherlands, Portugal and South Korea.

For another 10 countries, missing emancipative values in the third EVS/WVS have been estimated from existing emancipative values in the fourth EVS/WVS (about 2000). Estimates are obtained using the following regression equation (which explains 89 per cent of the variance across 27 countries): 'EmancVal1995 $=-0.16+1.00 *$ EmancVal2000'. Estimates have been assigned to the following countries: Egypt, El Salvador, Greece, Iran, Jordan*, Luxembourg, Malta, Poland, Uganda and Zimbabwe.

(*In the case of Jordan, New Zealand and Pakistan, aggregate measures of emancipative values have been calculated excluding 'tolerance of human diversity' (see the note to Table 2), since the relevant questions have not been asked there. Using the reduced scale of emancipative values, we identified the location of these three countries relative to all other countries. Then we translated their location to the complete scale of emancipative values using regression.)

\section{Notes}

1. Life satisfaction in the World Values Surveys is measured on a 10-point rating scale (as noted in the note to Table 2). Choice perception, too, is measured on a 10-point rating scale based on the following question (V82): 'Some people feel they have completely free choice and control over their lives, while other people feel that what they do has no real effect on what happens to them. Please use this scale where "1" means "none at all" and "10" means "a great deal" to indicate how much freedom of choice and control you feel you have over the way your life turns out.' In each of 148 of a total of 178 surveys where these variables can be created, there is a highly significant positive correlation. The average within-survey correlation points to 0.35 . Pooled across all surveys, the individual-level correlation is 0.42 . At the aggregate level of nations, the correlation is 0.85 . The individual-level correlation holds even controlling for financial satisfaction. See Note 3 below for data source.

2. Income and education are measured as an interaction term between individuals' years of schooling and their financial income, measured in deciles of national currencies. The correlation between this interaction term and individuals' emphasis on self-expression is significantly positive in 112 of a total of 120 surveys (94 per cent) where these variables could be created. Using years of schooling and financial income as sole correlates, the same applies to 95 and 94 per cent of the surveys, respectively.

3. Data from the first till the third wave of the World Values Surveys can be obtained from the International Consortium for Political Research (ICPSR) under the study number 
6160. Data from the fourth wave are not yet public domain. More detailed information on questionnaire, methods and fieldwork can be obtained from the World Values Study Group's homepage: http://wvs.isr.umich.edu. For the data provided by the European Values Study Group, see http://evs.kub.nl and Halman (2001).

4. Although these items are taken from the postmaterialism scale (see the notes to Table 2 ), we have reason to distinguish them as 'liberty aspirations' from other components of postmaterialism, namely preferences for a 'less impersonal society', 'beautiful cities' and 'a society in which ideas count more than money'. The postmaterialist interpretation implies that these are 'new' values that emerged only recently in postindustrial societies. We, however, believe this is not true in case of liberty aspirations, which are historically related to the rise of prosperous 'middle classes' as, for instance, in ancient Athens, in seventeenth-century England or in Southeast Asia during recent decades. This is argued in more detail by Welzel \& Inglehart (2001).

5. As noted by Barnes et al. (1979), signing petitions is a low-cost form of civic protest. Hence, a society with many people who sign petitions has a rich opportunity structure for low-cost protest. This in turn implies that there must be many people who invest the higher costs that are necessary to create low-cost opportunities for all.

6. Vanhanen creates three subindices. The subindex of 'physical resources' is generated from the share of family farms in the agricultural sector (weighted for the agricultural sector's share in GDP) and the de-concentration of non-agricultural resources (measured by 100 minus the share in GDP generated by the state, foreign enterprises and large national trusts). The subindex of 'intellectual resources' is measured by the number of students per 100,000 inhabitants and the literacy rate. The subindex of 'occupational diversification' ('social complexity', in our terminology) is produced from the proportion of the urban population and the percentage of the non-agricultural workforce. All component variables are standardized before they are combined to the subindices. The three subindices are each combined additively from their component variables, assuming that each subindex represents an own dimension. The same assumption then leads to a multiplicative combination of the three subindices to create the overall index of individual resources. This index is standardized to 100 as the maximum. For a detailed description of scale construction, see Vanhanen (1997: 42-63) and the appendices of his book for extensive documentation of data sources.

7. See Elkins (2000), who provides convincing theoretical reasons, plus empirical evidence, that Przeworski \& Limongi's (1997) pleading for a dichotomous classification of democracies versus non-democracies is flawed, and that continuous measures of democracy are preferable.

8. The Freedom House scores can be obtained from the homepage of Freedom House: http://www.freedomhouse.org. For a description of the estimation process and scale construction, see Freedom House (1996: 530-535). On the validity of these indices compared to other democracy scales, see Bollen \& Paxton (2000).

9. Transparency International is the world's leading NGO (nongovernmental organization) in the field of corruption watch. It gathers estimates on corruption from a variety of sources (including the World Bank, for example), summarizing these estimates into an overall corruption index. Data and a methodological report can be obtained from Transparency International's homepage: http://www.transparency.org.

10. The variable 'democratic tradition' measures the number of years that a country has spent under a democratic constitution. These years haven been counted from the beginning of a nation's independence (or from 1850 onward in case of countries that have 
been independent before 1850) until 1995. Countries that emerged from the dissolution of the Soviet Union and Yugoslavia have been dealt with like their former mother country as long as they belonged to it. A year has been counted as one under democratic constitution, if a country obtained at least +7 points on the 'Autocracy-Democracy' index from Jaggers \& Gurr (1995). This index is based on an analysis of constitutions considering the extent of restrictions on executive power and the voters' opportunities to influence politics. Jaggers \& Gurr (1995) classify countries as 'coherent democracies' if they reach +7 or more points on their -10 to +10 index. Data and a methodological description can be obtained from the homepage of the 'Polity 98' project: http://www.bsos.umd.edu/cidcm/polity. We used these data here because they reach farther back in time than the scores from Freedom House and are therefore more adequate to measure the endurance of the democratic tradition.

\section{References}

Almond, G.A. \& Verba, S. (1963). The civic culture. Princeton, NJ: Princeton University Press.

Anand, S. \& Sen, A. (2000). Human development and economic sustainability. World Development 28(12): 2029-2049.

Axelrod, R. (1984). The evolution of cooperation. London: Penguin Books.

Banfield, E.C. (1958). The moral basis of backwardness. Glencoe, IL: Free Press.

Barnes, S.H. et al. (1979). Political action. Beverley Hills, CA: Sage.

Barro, R.J. (1997). Determinants of economic growth. Cambridge, MA: MIT Press.

Bendix, R. (1974). Work and authority in industry. Berkeley, CA: University of California Press.

Blalock, H.M. (1961). Causal inferences in nonexperimental research. Chapel Hill, NC: University of North Carolina Press.

Bell, D. (1973). The coming of postindustrial society. New York: Penguin.

Birch, C. \& Cobb, J.B. (1981). The liberation of life. Cambridge: Cambridge University Press.

Blau, P.M. (1994). Structural contexts of opportunity. Chicago, IL: University of Chicago Press.

Brint, S. (1984). 'New class' and cumulative trend explanations of the liberal political attitudes of professionals. American Journal of Sociology 90(1): 30-71.

Bollen, K.A. \& Jackman, R.W. (1985). Political democracy and the size distribution of income. American Sociological Review 50(August): 438-457.

Bollen, K.A. \& Paxton, P.M. (2000). Subjective measures of liberal democracy. Comparative Political Studies 33(2): 58-86.

Budge, I. (1996). The new challenge of direct democracy. Cambridge: Polity Press.

Bürklin, W., Klein, M. \& Russe, A. (1996). Vom postmateriellen zum anthropozentrischen Wertewandel. Politische Vierteljahresschrift 37(4): 517-536.

Burkhart, R.E. \& Lewis-Beck, M.S. (1994). Comparative democracy: The economic development thesis. American Political Science Review 88(December): 903-910.

Casper, G. \& Taylor, M.M. (1996). Negotiating democracy. Pittsburgh, PA: University of Pittsburgh Press.

Chirot, D. (1986). Social change in the modern era. Orlando, FL: Harcourt Brace Jovanovich. 
Coleman, J.S. (1968). Modernization: Political aspects. in D.L. Sills (ed.), International Encyclopedia of the Social Sciences, Vol. 10. Washington, DC: Free Press, pp. 395-402.

Coleman, J.S. (1988). Social capital and the creation of human capital. American Journal of Sociology 94(Supplement): S95-S120.

Converse, P.E. (1970). Attitudes and non-attitudes. in E.R. Tufte (ed.), The quantitative analysis of social problems. Reading: Addison-Wesley, pp. 168-189.

Costa, P.T., McCrae, R.R. \& Zonderman, A.B. (1987). Environmental and dispositional influences on well-being. British Journal of Psychology 78: 299-306.

Cronin, T.E. (1999). Direct democracy, 2nd edn. Cambridge, MA: Harvard University Press.

Cummins, R.A. (2000). Objective and subjective quality of life. Social Indicators Research 52: 55-72.

Cutright, P.C. (1963). National political development. American Sociological Review 28(April): 253-264.

Dahl, R.A. (1973). Polyarchy. New Haven, CT: Yale University Press.

Dahl, R.A. (1998). Development and democratic culture. Journal of Democracy (9): 3439.

Dalton, R.J. (2001): Citizen Politics, 3rd edn. Chatham, NJ: Chatham House.

Diamond, L. (1992). Economic development and democracy reconsidered. in G. Marks \& L. Diamond (eds.), Reexamining democracy. London: Sage, pp. 93-139.

Diamond, L. (1993). The globalization of democracy. in R.O. Slater, B.M. Schutz \& S.R. Dorr (eds.), Global transformation and the Third World. Boulder, CO: Lynne Rienner, pp. 31-69.

Diener, E., Diener, M. \& Diener, C. (1995). Factors predicting the subjective well-being of nations. Journal of Personality and Social Psychology 69: 851-864.

Dorenspleet, R. (2000). Reassessing the three waves of democratization. World Politics 52(April): 384-406.

Doyal, G. \& Gough, I. (1991). A theory of human need. New York: Guilford Press.

Durkheim, É. (1988) [1893]. Über soziale Arbeitsteilung. Frankfurt: Suhrkamp.

Eckersley, R. (2000). The state and fate of nations: Implications of subjective measures of personal and social quality of life. Social Indicators Research 52: 3-27.

Eckstein, H.S. (1988). A culturalist theory of political change. American Political Science Review 82(4): 789-804.

Eisenstadt, S.N. (1986). The axial age breakthroughs. in S.N. Eisenstadt (ed.), The origins and diversity of axial age civilizations. New York: State University of New York Press, pp. $1-28$.

Elkins, Z. (2000). Gradations of democracy? American Journal of Political Science 44(April): $287-294$.

Ersson, S. \& Lane, J.-E. (1996). Democracy and development. in A. Leftwich (ed.), Democracy and development. Cambridge: Polity Press, pp. 45-73.

Estes, R.J. (1998). Trends in world social development. Journal of Developing Societies 14(1): 11-39.

Flanagan, S. (1987). Value change in industrial society. American Political Science Review 81(4): 1303-1319.

Feng, Y. (1997). Democracy, political stability and economic growth. British Journal of Political Science 27(3): 391-418.

Foweraker, J. \& Landman, T. (1997). Citizenship rights and social movements. Oxford: Oxford University Press. 
Freedom House (ed.) (various years). Freedom in the world. Lanham, MD: University Press of America.

Frey, R.S. \& Al-Roumi, A. (1999). Political democracy and the physical quality of life. Social Indicators Research 47: 73-97.

Fukuyama, F. (1995). Trust: Social virtues and the creation of prosperity. New York: Free Press.

Gasiorowski, M.J. \& Power, T.J. (1998). The structural determinants of democratic consolidation. Comparative Political Studies 31(December): 740-771.

Gibson, J.L. \& Duch, R.M. (1994). Postmaterialism and the emerging Soviet democracy. Political Science Quarterly 47: 5-39.

Goldstein, H. et al. (1998). A user's guide to Mlwin. London: Multilevel Models Project, University of London.

Gurr, T.R., Jaggers, K. \& Moore, W.H. (1990). The transformation of the Western state. Studies in Comparative International Development 25(1): 73-108.

Halman, L. (2001). The European values study. Tilburg: EVS, WORC, Tilburg University.

Heller, P. (2000). Degrees of democracy. World Politics 52(July): 484-519.

Helliwell, J.F. (1993). Empirical linkages between democracy and economic growth. British Journal of Political Science 24(April): 225-248.

Higley, J. \& Gunther, R. (eds.) (1992). Elites and democratic consolidation in Latin America and Southern Europe. New York: Cambridge University Press.

Hughes, B.B. (1999). International futures, 3rd edn. Boulder, CO: Westview Press.

Huntington, S.P. (1991). The third wave. Norman, OK: University of Oklahoma Press.

Huntington, S.P. (1996). The clash of civilizations and the remaking of the world order. New York: Simon \& Schuster.

Inglehart, R. (1977). The silent revolution. Princeton, NJ: Princeton University Press.

Inglehart, R. (1990). Culture shift in advanced industrial societies. Princeton, NJ: Princeton University Press.

Inglehart, R. (1997). Modernization and postmodernization. Princeton, NJ: Princeton University Press.

Inglehart, R. \& Baker, W.E. (2000). Modernization, cultural change and the persistence of traditional values. American Sociological Review 65(February): 19-51.

Inglehart, R. \& Welzel, C. (2003). Democratic institutions and political culture. Comparative Politics 35: forthcoming.

Inkeles, A. (1983). Exploring individual modernity. New York: Columbia University Press.

Inkeles, A. \& Smith, D.H. (1974). Becoming modern. Cambridge, MA: Harvard University Press.

Jackman, R.W. \& Miller, R.A. (1998). Social capital and politics. Annual Review of Political Science 1: 47-73.

Jaggers, K. \& Gurr, T.R. (1995). Tracking democracy's third wave with the Polity III data. Journal of Peace Research 32(4): 469-482.

Knack, S. \& Keefer, P. (1997). Does social capital have an economic payoff? Quarterly Journal of Economics 112: 1251-1288.

Kopstein, J.S. \& Reilly, D.A. (2000). Geographic diffusion and the transformation of the postcommunist world. World Politics 53(October): 1-37.

Kurzman, C. (1998). Waves of democratization. Studies in Comparative International Development 33(Spring): 42-64. 
Landes, D.S. (1998). The wealth and poverty of nations. New York: W.W. Norton.

Leblang, D.A. (1997). Political democracy and economic growth. British Journal of Political Science 27(3): 453-472.

Lerner, D. (1958). The passing of traditional society. New York: Free Press.

Lerner, D. (1968). Modernization: Social aspects. in D.L. Sills (ed.), The international encyclopedia of the social sciences, Vol. 10. New York: Free Press, pp. 386395.

Lewis, W.A. (1955). The theory of economic growth. Homewood, NJ: Richard D. Irvin.

Linz, J.J. \& Stepan, A. (1996). Problems of democratic transition and consolidation. Baltimore, MD: Johns Hopkins University Press.

Lipset, S.M. (1959). Some social requisites of democracy. American Political Science Review 53(March): 69-105.

Lipset, S.M., Kyoung-Ryung, S. \& Torres, J.C. (1993). A comparative analysis of the social requisites of democracy. International Social Science Journal 45(May): 155-175.

Macpherson, C.B. (1977). The life and times of liberal democracy. Oxford: Oxford University Press.

Maslow, A. (1988). Motivation and personality, 3rd edn. New York: Harper \& Row.

McAdam, D., Tarrow, S. \& Tilly, C. (2001). Contentious dynamics. Cambridge: Cambridge University Press.

Modelski, G. \& Perry, G. III (1991). Democratization in long perspective. Technological Forecasting and Social Change 39: 23-34.

Mouzelis, N. (1999). Modernity. British Journal of Sociology 50(March): 141-159.

Muller, E.N. (1997). Economic determinants of democracy. in M.I. Midlarski (ed.), Inequality, democracy and economic development. Cambridge: Cambridge University Press, pp. 133-155.

Muller, E.N. \& Seligson, M.A. (1994). Civic culture and democracy. American Political Science Review 88(3): 635-652.

Nagle, J.D. \& Mahr, A. (1999). Democracy and democratization. London: Sage.

Nevitte, N. (1996). The decline of deference. Ontario: Broadview Press.

Norris, P. (2002). Democratic phoenix. Cambridge: Cambridge University Press.

O'Donnell, G. \& Schmitter, P.C. (1986). Tentative conclusions about uncertain democracies. in G. O'Donnell, P.C. Schmitter \& L. Whitehead (eds.), Transitions from authoritarian rule, Vol. 4. Baltimore, MD: Johns Hopkins University Press, pp. 1-78.

Olson, M.J., Sarna, N. \& Swamy, A.W. (2000). Governance and growth. Public Choice 102: 341-364.

Page, B. \& Shapiro, R.Y. (1993). The rational public and democracy. in G.E. Marcus \& R.L. Hanson (eds.), Reconsidering the democratic public. University Park, PA: Pennsylvania State University Press, pp. 35-64.

Perkin, H. (1996). The third revolution. London: Routledge.

Przeworski, A. (1992). The games of transition. in S. Mainwaring, G. O'Donnell \& A. Valenzuela (eds.), Issues in democratic consolidation. Notre Dame, IN: University of Notre Dame Press, pp. 105-152.

Przeworski, A. \& Limongi, F. (1997). Modernization: Theories and facts. World Politics 49(January): 155-183.

Putnam, R.D. (1993). Making democracy work. Princeton, NJ: Princeton University Press.

Pye, L.W. (1990). Political science and the crisis of authoritarianism. American Political Science Review 84(March): 3-19. 
Randall, V. \& Theobald, R. (1998). Political change and underdevelopment. Durham, NC: Duke University Press.

Rawls, J. (1993). Political liberalism. New York: Columbia University Press.

Rodrik, D. (1999). The new global economy and developing countries. Washington, DC: Overseas Development Council.

Rokeach, M. (1960). The open and the closed mind. New York: Basic Books.

Rose, R. (2001). A diverging Europe. Journal of Democracy 12(1): 93-106.

Rostow, W.W. (1961). The stages of economic growth. Cambridge: Cambridge University Press.

Rowen, H.S. (1996). World wealth expanding. in R. Landau, T. Taylor \& G. Wright (eds.), The mosaic of economic growth. Stanford, CA: Stanford University Press, pp. 92-125.

Rustow, D.A. (1970). Transitions to democracy. Comparative Politics 2(April): 337-363.

Scarrow, S. (2001). Parties and the expansion of direct democracy. Party Politics (5):341-362.

Schmuck, P., Kasser, T. \& Ryan, R.M. (2000). Intrinsic and extrinsic goals. Social Indicators Research 50: 225-241.

Schwartz, S.H. (1992). Universals in the content and structure of values. in M.P. Zanna (ed.), Advances in social psychology. New York: Academic Press, pp. 1-65.

Sen, A. (2001). Development as freedom. New York: Alfred Knopf.

Sides, J. (1999). It takes two: The reciprocal relationship between social capital and democracy. Paper presented at the American Political Science Association annual meeting, Atlanta.

Simmel, G. (1984). Das Individuum und die Freiheit. Berlin: Duncker \& Humblodt.

Sørensen, G. (1993). Democracy and democratization. Boulder, CO: Westview Press.

Tooby, J. \& Cosmides, L. (1992). The psychological foundations of culture. in J.H. Barkow, L. Cosmides \& J. Tooby (eds.), The adapted mind. Oxford: Oxford University Press, pp. 19-136.

United Nations Development Program (eds.) (2000). Human Development Report 2000. New York: Oxford University Press.

Vanhanen, T. (1997). Prospects of democracy. London: Routledge.

Verba, S., Nie, N.H. \& Kim, J.-O. (1978). Participation and political equality. Cambridge: Cambridge University Press.

Weber, M. (1958) [1905]. The Protestant ethic and the spirit of capitalism. Boston: Allen \& Unwin.

Welzel, C. (2002). Fluchtpunkt Humanentwicklung. Opladen: Westdeutscher Verlag.

Welzel, C. (2003). Effective democracy, mass culture, and the quality of elites. International Journal of Comparative Sociology 43(3-5): 269-298.

Welzel, C. \& Inglehart, R. (2001). Human development and the 'explosion' of democracy. Berlin: WZB Discussion Paper FS III 01-202, WZB.

Yule, G.U. \& Kendall, M.G. (1950). An introduction to the theory of statistics. London: C. Griffin.

Zapf, W. \& Habich, R. (1999). Die Wohlfahrtsentwicklung in der Bundesrepublik Deutschland 1949-1999. in M. Kaase \& G. Schmid (eds.), Eine lernende Demokratie. Berlin: Sigma, pp. 285-314.

Address for correspondence: Christian Welzel, School of Humanities and Social Sciences, International University Bremen, PO Box 750 561, D-28725 Bremen, Germany.

E-mail: c.welzel@iu-bremen.de 